This PDF is a selection from a published volume from the National Bureau of Economic Research

Volume Title: Globalization in Historical Perspective

Volume Author/Editor: Michael D. Bordo, Alan M. Taylor and Jeffrey G. Williamson, editors

Volume Publisher: University of Chicago Press

Volume ISBN: 0-226-06598-7

Volume URL: http://www.nber.org/books/bord03-1

Conference Date: May 3-6, 2001

Publication Date: January 2003

Title: Does Globalization Make the World More Unequal?

Author: Peter H. Lindert, Jeffrey G. Williamson

URL: http://www.nber.org/chapters/c9590 


\title{
Does Globalization Make the World More Unequal?
}

\author{
Peter H. Lindert and Jeffrey G. Williamson
}

\subsection{Overview}

The world economy has become far more unequal over the last two centuries. Within-country income inequality has risen and fallen episodically. It has often risen in developing countries, although not always. It has fallen in the developed and industrialized countries, although this trend has recently reversed in some parts of the Organization for Economic Cooperation and Development (OECD). Thus, there is no ubiquitous trend in within-country inequality over the past two centuries. It follows that virtually all the observed rise in world income inequality has been driven by widening gaps between nations, and almost none of it has been driven by widening gaps within nations. Meanwhile, the world economy has become much more integrated. If correlation meant causation, these facts would imply that globalization has raised inequality between all nations but that it has not raised inequality within nations.

This essay argues that the likely impact of globalization on world inequality has been very different from what these simple correlations suggest. Globalization probably mitigated the steep rise in income gaps between nations. The nations that gained the most from globalization are

Peter H. Lindert is professor of economics at the University of California, Davis. Jeffrey G. Williamson is the Laird Bell Professor of Economics at Harvard University and a research associate of the National Bureau of Economic Research.

The authors thank François Bourguignon and Christian Morrisson for the chance to use prepublication estimates from their ongoing work on global inequalities. They also acknowledge with thanks the detailed comments of Alan Taylor on earlier drafts, discussions with David Dollar and Andy Warner, and comments made by participants at the NBER Globalization in Historical Perspective conference. Williamson gratefully acknowledges the financial support of the National Science Foundation SES-0001362. 
those poor ones that changed their policies to exploit it, whereas the ones that gained the least did not. The effect of globalization on inequality within nations has gone both ways, and not according to any simple correlation between the observed trends, or, for that matter, according to any simple theory.

The economic history of inequality suggests the following five conclusions about the influence of globalization:

1. The dramatic widening of income gaps between nations has probably been reduced, not raised, by the globalization of commodity and factor markets, at least for those countries that integrated into the world economy.

2. Within labor-abundant countries before 1914, opening up to international trade and to international factor movements lowered inequality, a powerful effect when and where emigration was massive.

3. Within labor-scarce countries, opening up to international trade and to international factor movements raised inequality, a powerful effect before 1914 where immigration was massive. Globalization also raised inequality in the postwar OECD, but it was not the main source of widening, partly because immigration was not massive either.

4. All international and intranational effects considered, more globalization has meant less world inequality.

5. World incomes would still be unequal under complete global integration, as they are in any large integrated national economy. But they would be less unequal in a fully integrated world economy than in one fully segmented.

This essay will reach these five conclusions by exploring four dimensions: the components of world inequality, the sources of globalization, the degree to which individual nations actually globalized, and the historical time period.

The two key components of world inequality - inequality between country average incomes, and inequality within countries - must be treated separately. Inequality between nations calls for attention to the determinants of per capita incomes. Inequality within countries calls for attention to the determinants of factor prices and their link to the size distribution of income. Even more importantly, international and intranational inequalities have very different implications for policy responses, and thus they demand separate attention. Changing world inequality induced by a changing distribution of population between countries also has different implications for policy, especially if induced by world migration. Finally, which components of world inequality matter most depends on whether observers care as much about the rest of the world as they care about their own citizens. This essay takes the global stance, but we warn again that national policies derive from national attitudes toward intranational globalization effects.

Different sources of globalization have different impacts on inequality. Po- 
litical debate over globalization implicitly poses an alternative in which liberal policy is replaced by barriers to trade and factor migration. Yet globalization in the past has been driven mostly by forces unrelated to policy, such as productivity improvements, rising potential gains from specialization, and transport revolutions, each of which may have very different implications for the distribution of world income compared with policy changes. Even when history offers examples of globalization due to more liberal policies, it matters who did the liberalizing.

Identical globalization events had very different effects on participants and non-participants. What globalization does to the inequality among participating countries is quite different from what it does to inequality among all nations. Controlling for other forces, we find clear signs of income convergence among countries that integrate more fully into the world economy, but divergence between these active participants and those who remain insulated from global markets. Among those participating in global markets, the already advanced countries, the regions of new settlement (European and otherwise), and the rest all experienced different effects: The gains from trade differed, the contribution of across-border factor flows differed, and the impact on their income distributions differed.

The historical record is divided into four distinctly different epochs: the pre-industrial years prior to the 1820 s; the long nineteenth century from the 1820 s to World War I; the two world wars and the unstable years in between; and the second half of the twentieth century. The first was a long preglobalization epoch in which factor flows were slight and long-distance trade was monopolized and mostly limited to luxuries. The second and fourth epochs contained worldwide surges in global integration. The third epoch witnessed a ubiquitous retreat from globalization into economic autarky.

\subsection{Global Divergence Is Far Older than Globalization}

To understand the long-run movements in world inequality and globalization, it is useful to begin by standing at the $1820 \mathrm{~s}^{1}$ watershed to survey the earlier and later trends from that vantage point.

From the 1820s onwards, there are better data on world inequality and world market integration. These data document some key facts. Fact number 1 is that all recent estimates find a dramatic income divergence around the globe over the past two centuries. Furthermore, they all show that this

1. The 1820 s represent a dating compromise. The decade is adopted in part to coincide with the peacetime recovery from the Napoleonic Wars on the Continent and an agricultural depression (i.e., structural adjustment) in Great Britain. The decade also serves as a link to Maddison's (1995) estimates for 1820 in his study of the world economy. Most important, however, the decade is consistent with the evidence put forth by O'Rourke and Williamson (2000) showing that international commodity price convergence did not start until then, and that a powerful and epochal move toward liberal policy (e.g., dismantling mercantilism) was manifested during that decade as well, at least in Great Britain. 


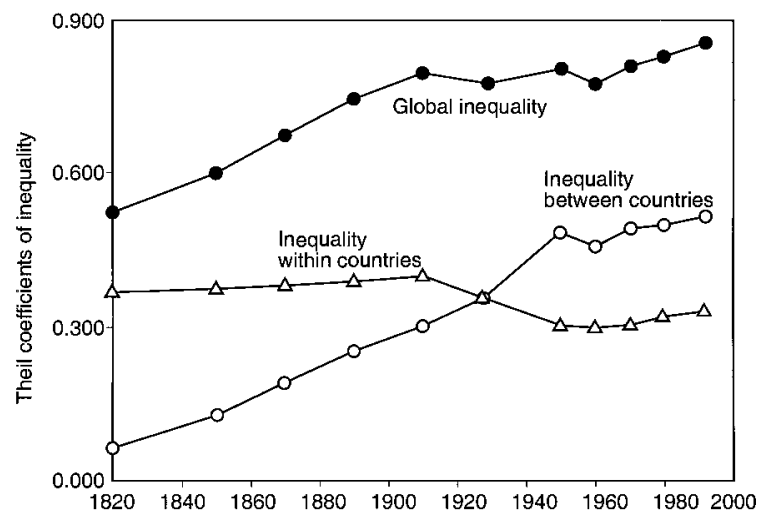

Fig. 5.1 Global inequality of individual incomes, 1820-1992

Source: Bourguignon and Morrisson (2002).

Notes: The "countries" here consist of fifteen single countries with abundant data and large populations, plus eighteen other country groups. The eighteen groups were aggregates of geographical neighbors having similar levels of GDP per capita, as estimated by Maddison (1995).

divergence has been driven almost entirely by the rise of between-nation inequality, not by any rise in inequality within nations (Berry, Bourguignon, and Morrisson, 1983, 1991; Maddison 1995; Pritchett 1997; Prados de la Escosura, 2000; Bourguignon and Morrisson 2002; Ward 2000). ${ }^{2}$ This evidence is summarized in figure 5.1. Fact number 2 is that, since the 1820 s, there has also been an impressive worldwide increase in commodity and factor market integration, despite the temporary and disastrous retreat during the world wars and the troubled era in between (Williamson 1995, 1996; Bordo, Eichengreen, and Irwin, 1999; O'Rourke and Williamson 1999). This evidence is summarized in table 5.1.

The centuries before 1820 offer two additional stylized facts. Fact number 3 is that income gaps almost certainly widened from 1600 or even earlier. As best we can judge from indicators of real wages, real land rents, returns to capital, and the occasional direct tax returns in the more literate countries, the early modern "great divergence" was true in all dimensions - globally and between European nations and within European nations. At the global level, real wages in England and Holland pulled away from the rest of the world in the late seventeenth and eighteenth century (van Zanden 1999; Pomeranz 2000; Allen 2000, 2001). Furthermore, the landed, merchant, and protomanufacturing classes of England, Holland, and France pulled

2. The rise in global income inequality from 1820 to 1950 illustrated in figure 5.1 has not been debated, but there is some disagreement about the experience since 1950. Although the Bourguignon and Morrisson (2002) data in figure 5.1 have the increase in global inequality and inequality between nations decelerating after 1950, the data in Melchior, Telle, and Wiig (2000) actually have the inequality between countries falling after 1960 . We shall have more to say about this epochal regime switch later. 


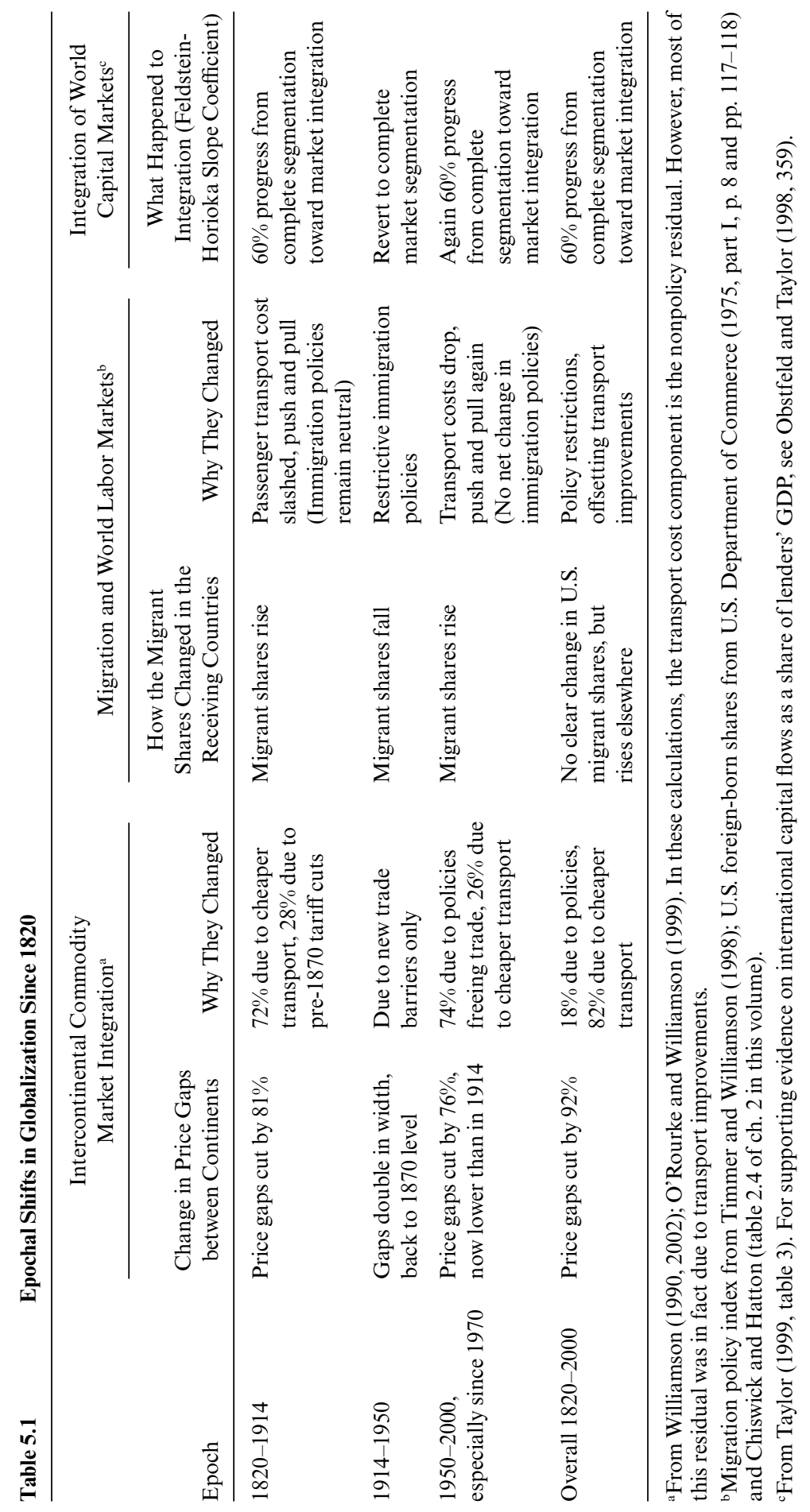


far ahead of everyone - their compatriots, the rest of Europe, and probably any nation in the world-between the sixteenth and the eighteenth centuries. This divergence was even greater in real than in nominal terms, because luxuries became much cheaper relative to staples (van Zanden 1995; Hoffman et al. 2002; Pamuk 2000). Although we still lack estimates or even guesstimates on the world distribution of income between 1500 and 1820, the bits and pieces we do have suggest that global inequality must have risen significantly in this pre-industrial era.

Fact number 4 is that there was no great march toward globalization after the 1490s and the voyages of de Gama and Columbus, despite the rhetoric about an early modern "world system." Granted, the early voyages made spice price markups a little less astronomical than in the days when the Arabs and Venetians monopolized long-distance trade. Yet there was no further progress toward price convergence in spices or any other longdistance tradable in the three centuries from the early and mid-1500s to the 1820s (O'Rourke and Williamson 2000, 2002; Findlay and O'Rourke, ch. 1 in this volume). Intercontinental trade remained effectively monopolized, and huge price markups between exporting and importing ports were maintained even in the face of improving transport technology. ${ }^{3}$ Furthermore, most of the traded commodities were noncompeting. That is, they were not produced at home and thus did not displace some competing domestic industry. In addition, these traded consumption goods were luxuries out of reach of the vast majority of each trading country's population. In short, pre-1820 trade had only a trivial impact on living standards of anyone but the very rich ${ }^{4}$ Finally, the migration of people and capital was only a trickle before the 1820s. True globalization began only after the 1820s.

These four facts imply the following conflict: Although global divergence has been, to use Pritchett's (1997) phrase, "big time" for at least 400 years, globalization has been a fact of life for only about 150 (from about 1820, but omitting the autarkic retreat in 1914-45). This conflict certainly raises initial doubts about the common premise that rising world integration is responsible for rising world inequality. ${ }^{5}$

3. Although the existence of multilateral trade helped harmonize price movements within Europe (Jacks 2000), price gaps remained wide, even for grains, which were the most traded goods in a highly segmented Europe. See Abel (1973,315, and tables 1 and 2) on the geography of wheat prices in grams of silver. At the local level, overland transport costs were typically higher than in the international sea trade, causing large markups over short distances. Another factor holding up grain trade integration between 1765 and the 1820s was the combination of the peacetime Corn Laws and the wartime Continental blockade.

4. For all the trade involving silver, its ability to buy grains or textiles remained far greater in Asia or even Eastern Europe than in the Americas, where the silver was mined, or in Western Europe. See O'Rourke and Williamson (2000) and Allen (2000) on Asia versus Europe, and Braudel and Spooner (1966), Allen (2001), and van Zanden (1999) on silver prices within Europe.

5. It should be added that, with the exception of sixteenth-century Spain, the countries that pulled ahead between 1500 and 1820 did not do so on the basis of their gains from overseas trade and empire, as quantitative studies have shown (e.g., Eltis and Engerman 2000). 


\subsection{The First Globalization Boom, 1820-1914}

Table 5.1 sketches the integration of world commodity and factor markets during the first great globalization boom and contrasts it with antiglobal trends after the start of World War I. Regarding trade and commodity markets, the liberal dismantling of mercantilism and the worldwide transport revolution worked together to produce truly global markets across the nineteenth century. Almost three-quarters of the commodity price convergence was due to declining transport costs, and a little more than a quarter was due to the liberal policy switch. ${ }^{6}$ Although the decline in transport costs continued throughout the century, there was an antiglobalization policy reaction only after 1870 , and it was nowhere near big enough to cause a return to the 1820 levels of economic isolation. Mass migration remained free, although immigrant subsidies had evaporated by the end of the century. As European investors came to believe in strong growth prospects overseas, global capital markets also became steadily more integrated, reaching levels in 1913 that may not yet have been regained even today. On all three fronts these pre-1914 globalization achievements were subsequently reversed, and then renewed after 1950 .

\subsubsection{Which Nations Gained Most from Trade? Terms-of-Trade Clues}

Terms-of-trade movements might offer some clues regarding who gains most from trade, and a literature at least two centuries old has offered opinions about whose terms of trade should improve most and why. ${ }^{7}$ Classical economists thought the relative price of primary products should rise given an inelastic supply of land and natural resources. This classical conventional wisdom took a revisionist U-turn in the 1950s when Hans Singer and Raoul Prebisch argued that the terms of trade had deteriorated for poor countries in the periphery, exporting primary products, while they had improved for rich countries in the center, exporting industrial products.

The terms of trade can be influenced by a decline in transport costs, in which case everybody's terms of trade can improve. They can also be influenced by policy and by other events, such as intercommodity differences in productivity growth rates, demand elasticities, and factor supply responses. Since transport costs declined sharply in the century following 1820 , this is one likely source that served to raise everybody's terms of trade. Furthermore, and as we shall see in a moment, rich countries like Great Britain took a terms-of-trade hit when they switched to free trade by midcentury, an event that must have raised the terms of trade in the poor, nonindustrial periphery even more. But in some parts of the periphery, especially before the 1870 s, other factors were at work that mattered even more.

6 . The relative contribution of the liberal policy switch between the 1770 s and the 1820 s, associated with rejecting mercantilism, was, of course, far bigger.

7. See the survey in Diakosavvas and Scandizzo (1991) or Hadass and Williamson (2001). 
Probably the greatest nineteenth-century globalization shock did not involve transport revolutions at all. It happened in Asia, and it happened shortly before 1870 . Under the persuasion of American gunships, Japan switched from virtual autarky to free trade in 1858. It is hard to imagine a more dramatic switch from closed to open trade policy. In the fifteen years following 1858, Japan's foreign trade rose seventy times, from virtually nil to 7 percent of national income (Huber 1971). The prices of exportables soared, rising toward world market levels. The prices of importables slumped, falling toward world market levels. One researcher estimates that, as a consequence, Japan's terms of trade rose by a factor of 3.5 between 1858 and the early 1870s (Huber 1971). Another thinks the rise was even bigger, a factor of 4.9 between 1857 and 1875 (Yasuba 1996). Whichever estimate one accepts, the combination of declining transport costs and a dramatic switch from autarky to free trade unleashed a powerful terms-of-trade gain for Japan.

Other Asian nations followed this liberal path, most forced to do so by colonial dominance or gunboat diplomacy. Thus, China signed a treaty in 1842 opening her ports to trade and adopting a 5 percent ad valorem tariff limit. Siam adopted a 3 percent tariff limit in 1855. Korea emerged from its autarkic "hermit kingdom" a little later (with the Treaty of Kangwha in 1876), undergoing market integration with Japan long before colonial status became formalized in 1910. India went the way of British free trade in 1846, and Indonesia mimicked Dutch liberalism. In short, and whether they liked it or not, prior to 1870 the most important part of the periphery underwent tremendous improvements in their terms of trade by this policy switch, and it was reinforced by declining transport costs worldwide.

For the years after 1870, we have good evidence documenting terms-oftrade movements the world around (Williamson 2002, table 2). Contrary to the assertions of Prebisch and Singer, not only did the terms of trade improve for the poor periphery ${ }^{8}$ up to World War I, but they improved a lot more than they did in Europe. Over the four decades prior to World War I, the terms of trade rose by only 2 percent in the European center, by almost 10 percent in East Asia, and by more than 21 percent in the rest of the third world.

These pre-World War I terms-of-trade clues seem to imply that globalization favored the poor periphery more than it did the center, and thus that globalization contained leveling forces. The inference may be false.

Over the short run, positive and quasi-permanent terms-of-trade shocks of foreign origin will always (ceteris paribus) raise a nation's purchasing power, and the empirical issue is only how much. If the export sector was

8. In the study cited (Williamson 2002), the poor periphery sample includes Burma, Egypt, India, Japan, Korea, Taiwan, and Thailand. The rich (New World) periphery sample includes Argentina, Australia, Canada, the United States, and Uruguay. The Europe center sample includes Great Britain, Denmark, France, Germany, Ireland, Spain, and Sweden. 
one-fifth of gross domestic product (GDP; a very large share by the standards of that time), and if the terms of trade improved by 5 percent over a decade (a pretty big relative price shock, as we have seen), then the purchasing power of GDP would have been raised by about 0.1 percentage points a year, a pretty small bang even if the country was growing at only 1 or 2 percent per annum.

Over the long run a positive terms-of-trade shock in primary-productproducing countries could reinforce comparative advantage, pull resources into the export sector from other activities, and cause deindustrialization. To the extent that industrialization is the prime carrier of capital-deepening and technological change, then economists like Hans Singer are right to caution that positive external price shocks for primary producers may actually lower growth rates in the long run. As far as we know, nobody has yet tried to decompose the short-run and long-run components of terms-oftrade shocks like these. But there has been a recent effort to explore the possibility that a positive change in the terms of trade could have had a negative long-run effect around the periphery. ${ }^{9}$

\subsubsection{Trade Expansion and the Within-Country Distribution of Income}

The standard Stolper-Samuelson prediction is that free trade increases incomes for the abundant factor and reduces incomes for the scarce factor. Protection has the opposite effect, and what holds for trade policy also holds for transport costs. In a simple world where labor works the land, and where each country takes world commodity prices as given, any move toward the globalization of commodity markets through trade and commodity price convergence should favor incomes of the laboring poor in the poorest trading partners where labor is abundant and land is scarce. Conversely, it should favor incomes of the landed rich in the richest trading partners where labor is scarce and land is abundant. But suppose there are more factors of production than just land and labor, and suppose some countries have an impact on their terms of trade. What then? History offers plenty of competing examples.

9. Hadass and Williamson (2001). Adding terms-of-trade variables to empirical growth models in the tradition of Robert Barro, Jeffrey Sachs, and many others (Barro and Sala-i-Martin 1995; Sachs and Warner 1995), and estimating for a panel of nineteen countries between 1870 and 1940, yields the result that an improvement in terms of trade augmented growth in the center. That is, the coefficient on terms-of-trade growth in the center is positive and significant in a GDP per capita growth regression. However, the same positive terms-of-trade shock was growth-reducing in the periphery. It appears that the short-run gain from an improving terms of trade was overwhelmed by a long-run loss attributed to deindustrialization in the periphery; in the center, in contrast, the short-run gain was reinforced by a long-run gain attributed to industrialization. Thus, it looks like terms-of-trade shocks before World War I were serving to augment the growing gap between rich and poor nations, with globalization adding to divergence. However, terms-of-trade shocks were rarely big enough to change GDP per capita growth rates by more than 5 or 10 percent (e.g., from 2 to 2.1 or 2.2 percent per annum). 
Great Britain's nineteenth-century free-trade leadership, especially its famous Corn Law repeal in 1846, offers a good illustration of how the effects of liberalization depend on its sources, and how the effects of globalization can be egalitarian both at the world level and within the liberalizing advanced country. Was this a redistribution toward the British rich and away from the British poor, as well as from the rest of the world, as some of today's rhetoric would insist? No, the most likely redistributive effects were just the opposite. The big gainers from this leading-country trade liberalization were British laborers and the rest of the world, while the clear losers were British landlords, the world's richest group. How much the rest of the world gained (and whether British capitalists gained at all) depended on foreign-trade elasticities and induced terms-of-trade effects, assessments that pitted David Ricardo against Robert Torrens. But since these terms-oftrade effects were probably quite significant for what then was called "the workshop of the world," Great Britain must have distributed considerable gains to the rest of the world as well as to her own workers. British labor gained because Great Britain was a food-importing country (thus agriculture was a small employer) ${ }^{10}$ and unskilled labor was used much less intensively in import-competing production than was land. ${ }^{11}$ British nineteenthcentury experience offers a very different example than does the United States today, as we shall see below. Thus, history offers two enormously important historical cases in which leading-country trade liberalization had completely different effects: whereas British liberalization in the nineteenth century was unambiguously egalitarian at both the national and global level, American liberalization in the twentieth century was not.

There are even better data for exploiting the factor-price approach to the globalization and inequality connection after 1870, but while we examine these data remember that international factor migration joined trade as an important force affecting intranational inequality in the late nineteenth century. Two kinds of evidence offer hints about inequality trends within countries participating in the global economy (Williamson 1997). One uses trends in the ratio of farm rents per acre to unskilled wages $(r / w$, in figs. 5.2 and 5.4). ${ }^{12}$ The rent-wage ratio might be thought of as a measure of how

10. O'Rourke (1997) has shown that labor would not have gained from free trade on much of the continent because, among other things, agriculture was a much bigger employer, so that the employment effects (the nominal wage) dominated the consumption effects (the cost of living).

11. See Irwin $(1988,1991)$ and Williamson (1990). The effects on specific factor-income groups within Great Britain are inferred from a computable general-equilibrium model, one that is outfitted with parameters from nineteenth-century Great Britain, and one that is broadly consistent with observed movements in relative factor prices. The effects on Great Britain's terms of trade are estimated econometrically from British time series data.

12. The sources for figures 5.2-5.5 are O'Rourke, Taylor, and Williamson (1996) and Williamson (2002). For expositional convenience, this section examines factor-price ratios as if they were being affected by commodity trade alone, even though the same factor-price movements were affected strongly by the international factor flows to which we will turn next. This 


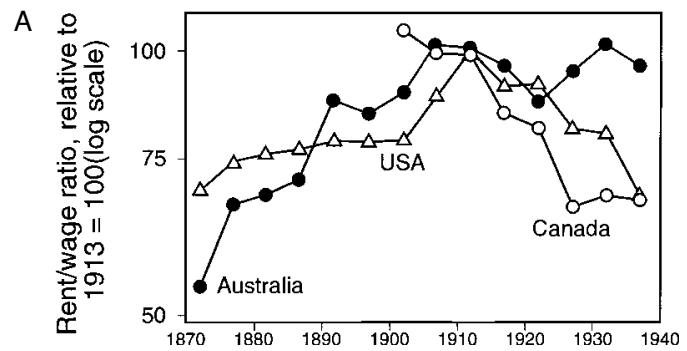

B

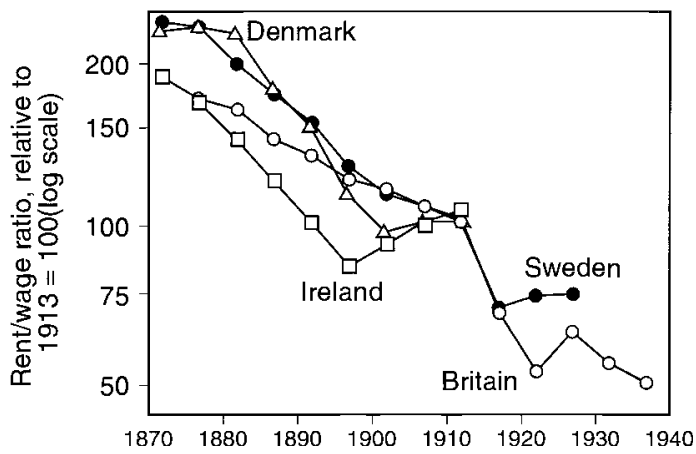

C

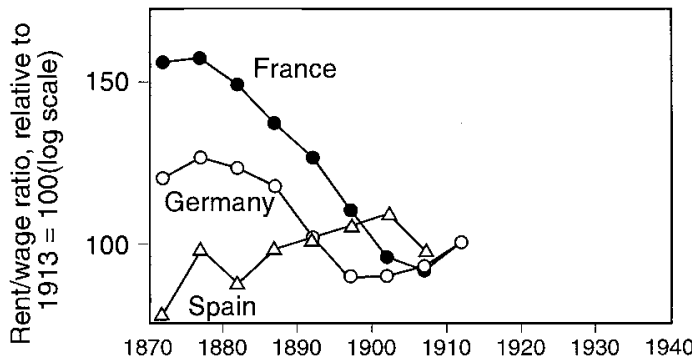

Fig. 5.2 Trends in the rent-wage ratio, Europe and the New World, 1870-1939: $A$, Initially land-abundant countries; $B$, Land-scarce free-trade countries; $C$, Landscarce countries protecting grain farmers after 1875

Source: See note 12.

many days' labor it would take to pay the rent on a hectare of farmland. It is a relative factor price whose trends determined inequality movements in

expositional assumption seems harmless since econometric analysis confirms that both trade and factor flows contributed to the movements documented in figures 5.2-5.5 (O'Rourke, Taylor, and Williamson). We should note that the land "rents" are in fact indexes of farmland purchase prices, not rents, in the case of Australia, Punjab, Sweden, Thailand, and the United States. The ratio of land purchase value to rental value could have drifted upward due to reduction in nominal interest rates. For these countries, the rise in the ratio of land value to wages could overstate (understate) the rise (decline) in the rent-wage ratio to the extent that interest rates were falling. 
A

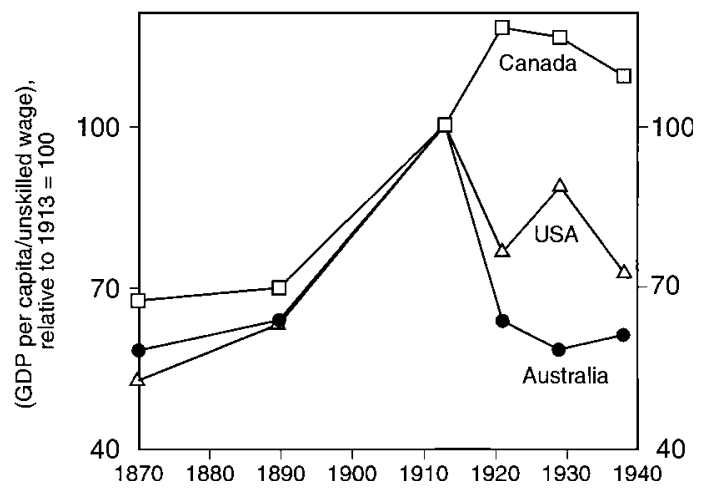

B

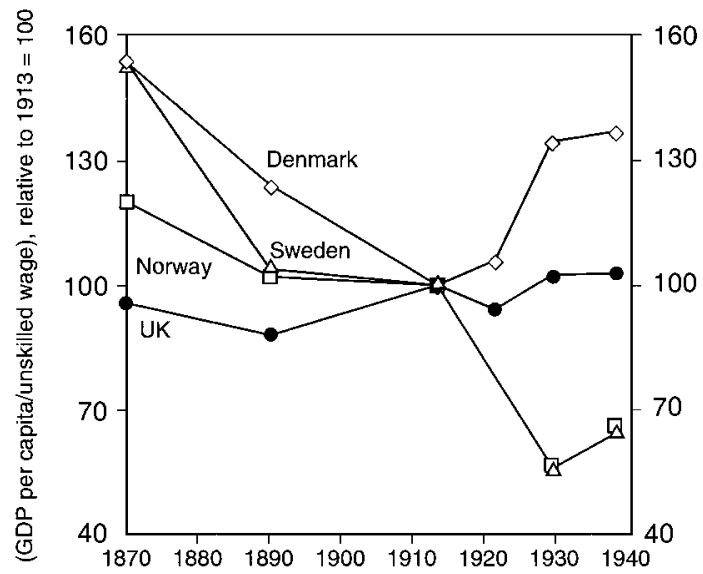

Fig. 5.3 Trends in a crude inequality indicator, Old and New World, 1870-1939: $A$, Initially land-abundant countries; $B$, Land-scarce free-trade countries

Source: See note 12.

a world where the agricultural sector was big and where land was a critical component of total wealth. It tells us how the typical landlord at the top of the distribution did relative to the typical unskilled (landless) worker near the bottom. The other inequality clue from factor prices uses trends in the ratio of GDP per worker to the unskilled wage rate ( $v / w$, in figs. 5.3 and 5.5). These tell us how far the recipient of the average income was pulling ahead of the typical unskilled worker near the bottom. ${ }^{13}$ We now have this evidence for the Atlantic economy. Figure 5.3 plots trends in $y / w$, and it is certainly consistent with the conventional globalization prediction. Inequality

13. Our references to "top," "middle," and "bottom" do not mean that the landlords, average income earners, and unskilled workers occupied fixed percentile positions on the income spectrum. This assumption would be convenient here, but the data do not allow it. 

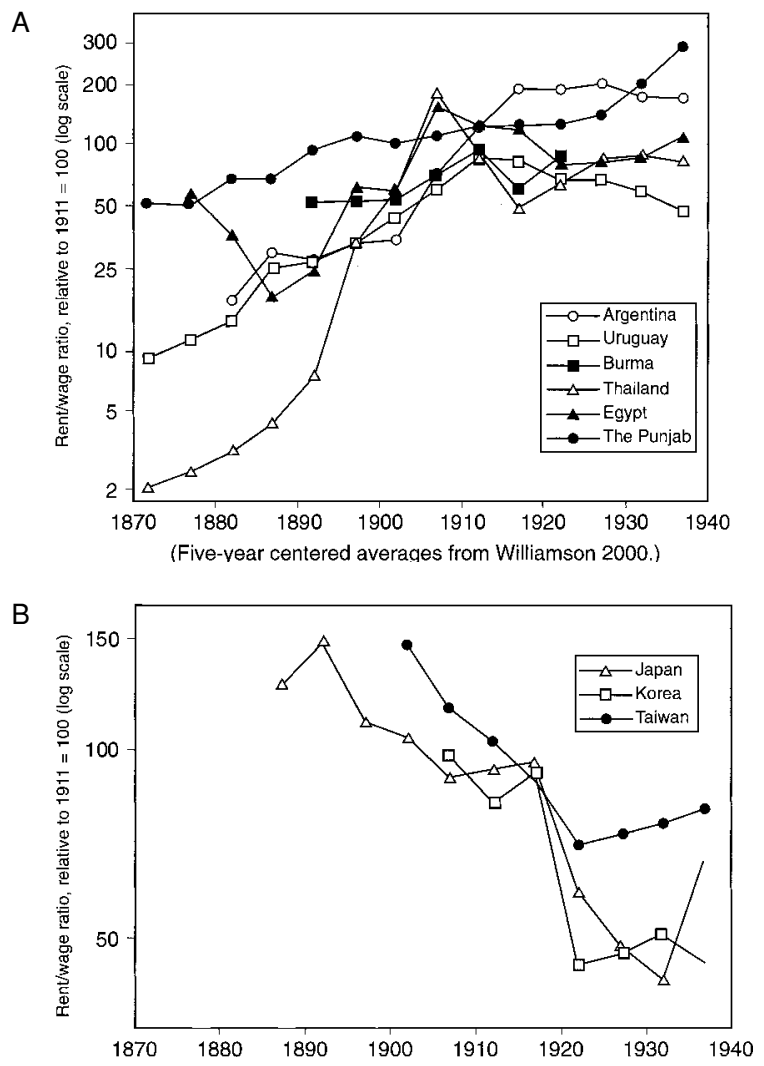

Fig. 5.4 Third world trends in rent-wage ratios, 1870-1939: $A$, Initially landabundant countries; $B$, Land-scarce countries

Source: See note 12.

should have been rising in labor-scarce and land-abundant countries either due to the trade boom raising incomes of the abundant factor (e.g., land, augmenting incomes of those at the top) or due to a mass immigration lowering unskilled wages (e.g., unskilled labor, eroding incomes of those near the bottom).

A strong link between inequality trends and initial endowment stands out in figures 5.2-5.5, and this link bears the clear imprint of a globalization effect. Our first glimpse of the link comes from the contrasting trends for land-abundant North America and Australia versus land-scarce Europe in figure 5.2. In North America and Australia, where land was initially abundant, rents rose relative to unskilled wages before World War I, although not for the deglobalizing interwar period. The same was true of the initially land-abundant countries of Latin America and Asia, as shown in figure 5.4. By contrast, where land was initially scarce, as in Europe, Japan, Korea, 

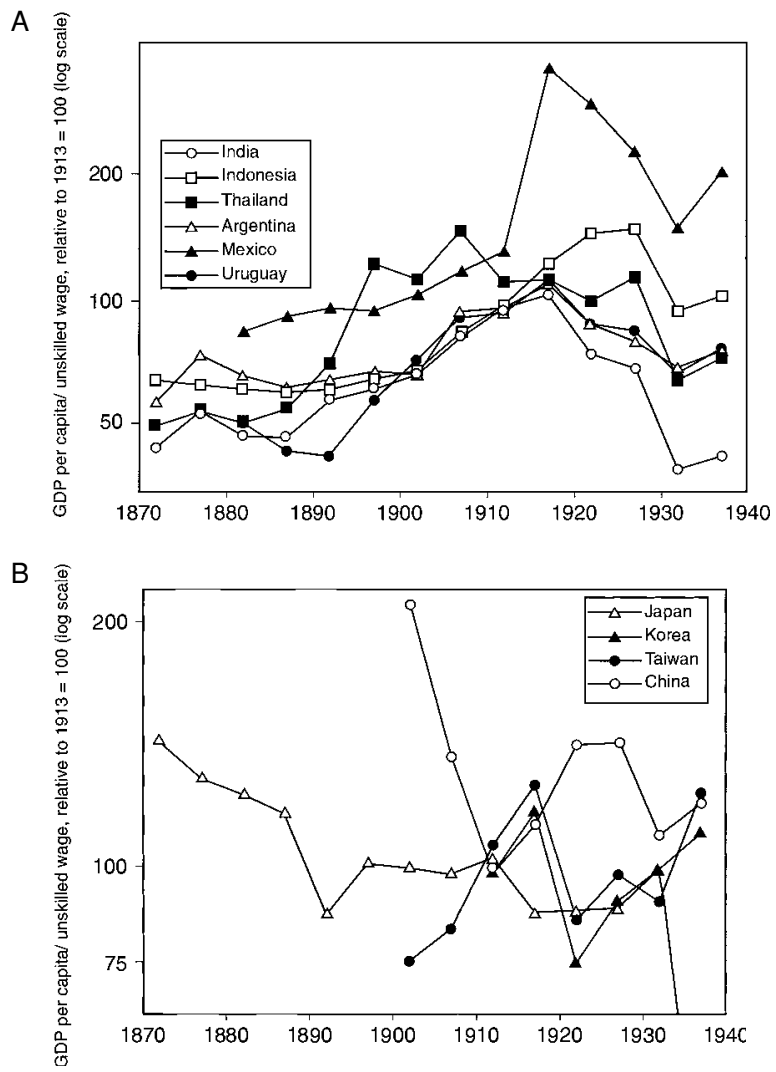

Fig. 5.5 Third world trends in a crude inequality indicator, 1870-1939: $A$, Initially land-abundant countries; $B$, Land-scarce countries

Source: See note 12.

and Taiwan, the rent-wage ratio declined before 1914. Although many factors were at work, globalization must have played the key role in accounting for the sharply contrasting trends between land-abundant and landscarce countries, and between globalizing prewar and deglobalizing interwar periods. We cannot imagine another causal force that by itself could explain these sharp contrasts in trend between countries and periods, especially in those where industrialization forces were quiet.

Trends within Europe also betray an important distributional role for globalization. Note in figure 5.2 that those who faced the onslaught of cheap foreign grain after 1870, but decided not to impose high tariffs on the invading grains (Great Britain, Ireland, Denmark, and Sweden), recorded the biggest loss on rental income for landlords and the biggest gain for workers. Those who protected their landlords and farmers against cheap foreign grain after 1875 (France, Germany, and Spain) generally recorded a smaller decline in land rents relative to unskilled wage rates. 
Inequality should have been falling in labor-abundant and land-scarce European countries, again due to trade booms and mass emigration. That happened in Scandinavia and Italy. Portugal and Spain did not share these egalitarian trends, but Iberia was well known for its unwillingness to play the globalization game. The European industrial leaders fell in the middle, just as we would predict. They were, after all, industrial and thus had smaller agricultural sectors. Land was a smaller component of total wealth in these industrial leaders, and improved incomes for (abundant) capital, whose capitalist owners were located near the top of the income distribution, at least partially offset the diminished incomes from land, whose owners tended to be at the top of the income distribution.

Evidence supporting these rent-wage ratio inferences come from the behavior of the second crude inequality indicator $(y / w)$ in figures 5.3 and 5.5. It rose in the land-abundant countries during the prewar globalization boom. It declined in the land-scarce countries (with the possible exception of East Asia between the 1890s and World War I).

The inequality-globalization connection in the nineteenth century can be summarized this way: Globalization seems to have had an inegalitarian effect in (initially) land-abundant countries, a force raising inequality by rewarding landowners more than workers; and globalization seems to have had an egalitarian effect in (initially) land-scarce countries, especially in those that stuck with free trade and resisted pleas for protection. These two effects might appear at first glance to cancel each other out when aggregating up to the Atlantic economy as a whole. But a longer look tips the scales in favor of net egalitarian effects when we note that European landlords at the top of the Atlantic income distribution lost the most, while European unskilled workers at the bottom gained the most. A lot of the rest was simply New World "churning" in the middle.

\subsubsection{The Impact of Factor Migration on Between-Country Income Gaps}

\section{Mass Migration and Convergence}

Real wages and living standards converged among the currently industrialized OECD countries between 1850 and World War I. The convergence was driven primarily by the erosion of the gap between the New World and the Old. In addition, many poor European countries were catching up with the industrial leaders. How much of this convergence was due to mass migration? ${ }^{14}$ Although Barry R. Chiswick and Timothy J. Hatton discuss this question in chapter 2 in this volume, we must treat the issue here too.

Table 5.2 assesses the labor force impact of these migrations on each of seventeen countries in the Atlantic economy in 1910. The impact varied greatly. Among receiving countries, Argentina's labor force was augmented

14. This section draws heavily on O'Rourke and Williamson (1999, 160-66). 


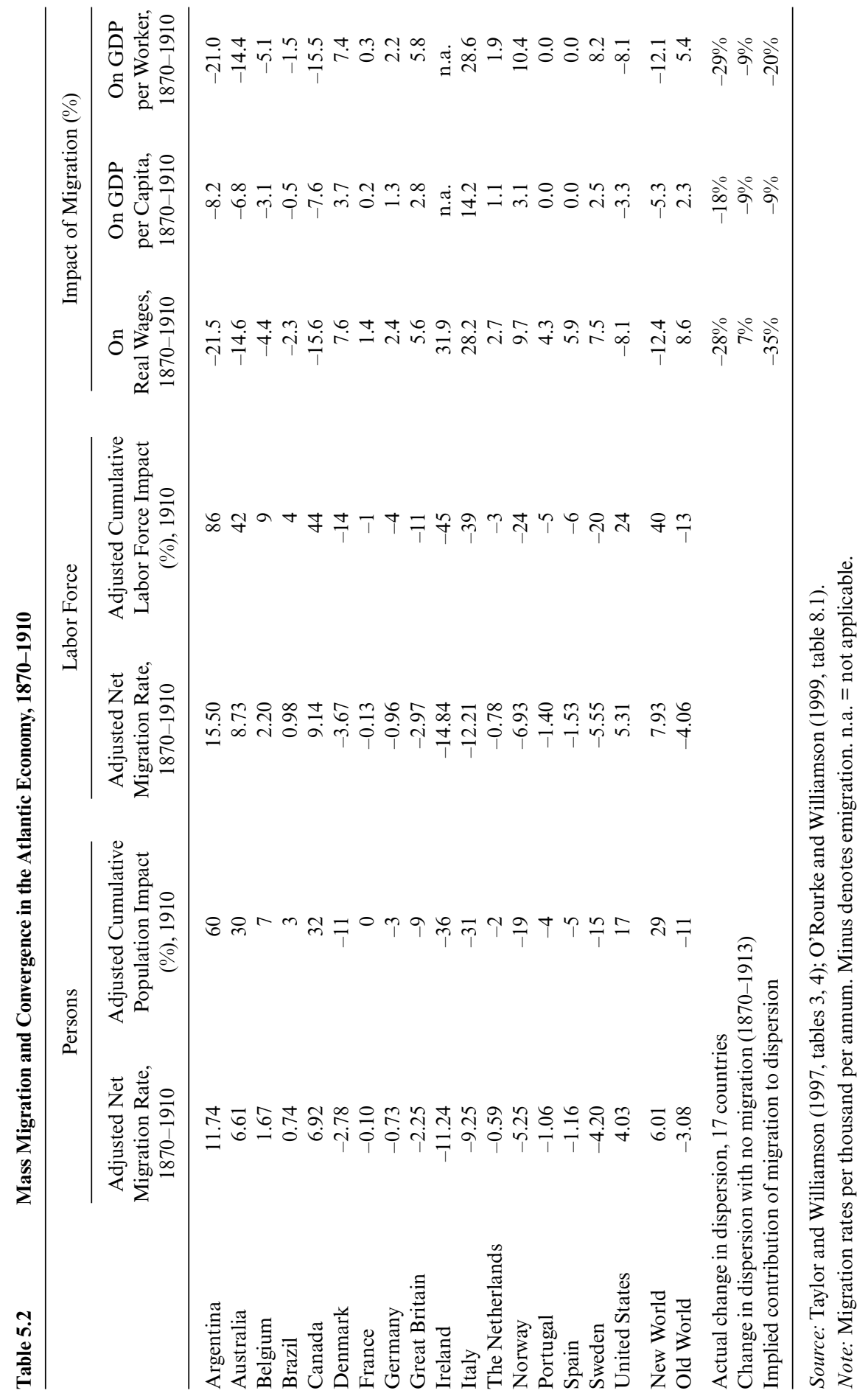


most by immigration ( 86 percent), Brazil's the least ( 4 percent), and the United States in between (24 percent), the latter below the New World average of 40 percent. Among sending countries, Ireland's labor force was diminished most by emigration ( 45 percent), France the least ( 1 percent), and Great Britain in between (11 percent), the latter just a little below the Old World average of 13 percent. At the same time, real wage dispersion in the Atlantic economy declined between 1870 and 1910 by 28 percent, GDP per capita dispersion by 18 percent, and GDP per-worker dispersion by 29 percent (table 5.2, bottom). What contribution did the mass migration make to that measured convergence? To answer this question, we ask another: What would have been the measured convergence had there been no mass migration?

Migration affects long-run equilibrium output and wages by influencing aggregate labor supply. Taylor and Williamson (1997) estimate labor demand elasticities econometrically and use these results to assess the wage impact of changing labor supply by country. They also estimated the impact of migration on GDP per capita and GDP per worker. The last three columns of table 5.2 present their results.

Table 5.2 accords with intuition. In the absence of the mass migrations, wages and labor productivity would have been a lot higher in the New World and a lot lower in the Old. In the absence of the mass migrations, income per capita would typically (but not always) have been a bit higher in the New World and typically (but not always) a bit lower in the Old World. Not surprisingly, the biggest counterfactual impact is reported for those countries that experienced the biggest migrations. Emigration raised Irish wages by 32 percent, Italian by 28 percent, and Norwegian by 10 percent. Immigration lowered Argentine wages by 22 percent, Australian by 15 percent, Canadian by 16 percent, and American by 8 percent.

This partial equilibrium assessment of migration's impact is higher than a general equilibrium assessment would be. After all, it ignores trade responses and changes in output mix, both of which would have muted the impact of migration. It also ignores global capital market responses, although this latter shortcoming will be repaired in a moment. Whether an overstatement or not, table 5.2 certainly lends strong support to the hypothesis that mass migration made an important contribution to latenineteenth-century convergence. In the absence of the mass migrations, real wage dispersion would have increased by 7 percent, rather than decreasing by 28 percent, as in fact it did (table 5.2, bottom panel). Gross domestic product per-worker dispersion would have decreased by only 9 percent, rather than by 29 percent, as in fact it did. GDP per capita dispersion would also have decreased by only 9 percent, rather than by 18 percent as in fact it did. Wage gaps between New World and Old in fact declined from 108 to 85 percent, but in the absence of the mass migrations they would have risen to 128 percent in 1910 . 
Using results like those in table 5.2, Taylor and Williamson (1997) conclude that for 1870-1910 migration can account for all of the real wage convergence, about two-thirds of the GDP-per-worker convergence, and perhaps one-half of the GDP per capita convergence. ${ }^{15}$

The relative insensitivity of GDP per capita convergence to migration is a result of countervailing effects. Mass migration self-selected young adults. Thus, high migrant labor participation rates amplified the impact of migration on real wages and GDP per worker, but the effect on GDP per capita was muted. Why? For wages and GDP per worker, migration has a bigger impact the bigger its labor content. In the case of GDP per capita, things are less clear because there are two offsetting forces at work. Population emigration reverses diminishing returns, yielding a positive impact on output per capita; but selectivity assures that emigration will also take away a disproportionate share of the labor force, lowering output via labor supply losses, yielding a negative impact on output per capita. ${ }^{16}$ The latter effect dominated in the late-nineteenth-century Atlantic economy, so muted GDP per capita effects are no surprise. Based on table 5.2, we can conclude that four decades of migration never lowered New World GDP per capita by more than 9 percent anywhere in the New World, and by as little as 3 percent in the United States, in contrast with per-worker impacts of 21 and 8 percent, respectively. ${ }^{17}$ Similar reasoning applies to the Old World: Swedish emigration after 1870 may have raised wages in 1910 by about 8 percent, but it served to raise Sweden's GDP per capita by only 3 percent.

\section{Mass Migration and Global Inequality}

An important extra effect of the great migration on global inequality has been omitted from the accounting so far. Table 5.2 was constructed to show the effect of migration on convergence in per capita and per-worker aver-

15. The contributions of mass migration to convergence in the full sample and within the New and Old World differ, the intraregional effects being smaller. Furthermore, in two New World countries, Argentina and Brazil, global convergence would have been greater in the absence of mass migration. The fact that the Atlantic labor market was segmented should account for this otherwise bizarre result. Immigrant flows were not efficiently distributed everywhere, because barriers to entry limited destination choices for many southern Europeans, a point central to discussions of Latin American economic performance (Diaz-Alejandro 1970; Hatton and Williamson 1998, chaps. 2, 3, 6, and 10). Thus, migrants did not always obey some simple market-wage calculus; kept out of the best high-wage destinations, or having alternative cultural preferences, many went to the "wrong" countries. The South-South flows from Italy, Spain, and Portugal to Brazil and Argentina were a strong force for local (Latin), not global (Atlantic), convergence. Furthermore, while barriers to exit were virtually absent in most of the Old World, policy in the New World (like assisted passage) still played a part in violating any simple market-wage calculus.

16. This argument assumes that immigrant remittances - while substantial - were nowhere near large enough to erase the first-order "perverse" effect on GDP per capita.

17. This labor-supply compensation effect operated in addition to the usual human-capital transfer influences invoked to describe the net benefit to the United States of the immigrants received before WWI (Neal and Uselding 1972). 
ages between countries; it was not constructed to show the impact of migration on income distribution within the Atlantic economy as a whole. To do so, we need to add on the large income gains accruing to the 60 million Europeans who moved overseas. Typically, they came from countries whose average real wages and average GDP per worker were perhaps only half of those in the receiving countries. These migrant gains were an important part of their net equalizing effect on world incomes, and even on "world" income distribution among the seventeen countries in table 5.2.

\section{Capital Flow Responses?}

Using ceteris paribus assumptions, we earlier concluded that mass migration accounted for all of the real wage convergence observed in the Atlantic economy between 1870 and 1910. But other things were not constant. There were other powerful proconvergence and anticonvergence forces at work, capital accumulation being one of them. We know that capital accumulation was rapid in the New World, so much so that the rate of capital deepening was faster in the United States than in any of its European competitors (Wright 1990; Wolff 1991), and the same was probably true of other rich New World countries. Thus, the mass migrations may have been at least partially offset by capital accumulation, and a large part of that capital widening was being carried by international capital flows that reached magnitudes unsurpassed before or since, as Obstfeld and Taylor show in chapter 3 in this volume. The evidence on the role of global capital market responses to migration is very tentative, but Taylor and Williamson (1997, tables 4-6a) make exactly this kind of adjustment. They implement the zero-net-migration counterfactual in a model where the labor supply shocks generate capital inflows or outflows in order to maintain a constant rate of return on capital in each country (e.g., perfect global capital market integration). The capital-chasing-labor offsets are very large. Whereas mass migration explained all of the observed real wage convergence using the model without capital chasing labor, it explains about 70 percent of the convergence using the model with capital chasing labor, leaving only about 30 percent to other forces. The findings for labor productivity are similar.

\section{Capital Flows, Convergence, and the Lucas Paradox}

Although it is true that capital markets were at least as well integrated globally prior to World War I as they are today, capital flows were mainly an anticonvergence force. This apparently counterintuitive statement is, of course, inconsistent with a simple theory predicting that capital should flow from rich countries (presumably capital abundant) to poor countries (presumably capital scarce). It did not. Just as Lucas (1990) reported for the late twentieth century, Clemens and Williamson (2000) find that capital inflows and GDP per capita were positively correlated between 1870 and 1913. The so-called Lucas paradox was alive and well a century ago, and it is explained 
by the fact that capital chased after abundant natural resources, youthful populations, and human-capital abundance. Thus, capital flows were an anticonvergence force. They drifted toward rich, not poor, countries; they raised wages and labor productivity in the resource-abundant New World; and, with the exception of Scandinavia, their exit from Europe lowered wages and labor productivity in that resource-scarce part of the world.

\subsubsection{Summing Up: Nineteenth-Century Convergence Forces in a Diverging World}

Among the main participants in the nineteenth-century economy, globalization had offsetting effects. Within rich, land-abundant New World countries, more trade and more immigration augmented inequality. Within poor, primary-product-exporting third world countries, they did the same. Within poor, land-scarce, participating Old World countries, more trade and more emigration reduced inequality. As for income gaps between countries, migration had an equalizing effect, one that was somewhat offset by the fact that capital flowed to rich New World countries. Freer trade might also have had an egalitarian effect, benefiting the poorer new participants like Japan the most, although it may not have favored peripheral counties that were led into deindustrialization. Overall, prewar globalization looks like a force equalizing average incomes between the participating countries, but with mixed effects on inequality within participating countries.

If globalization had mixed effects that probably tilted a bit toward global equalization among the countries involved, why does world income inequality rise so much in figure 5.1? One answer, of course, is that average national incomes were driven apart by more fundamental forces, such as inequalities in schooling, secure property rights, and government quality. Another answer is that there were no mass migrations between poor periphery and rich center. ${ }^{18} \mathrm{~A}$ third answer is that many countries remained detached from the global economy by choice (e.g., Iberia) or by distance (e.g., much of inland Africa, Asia, and Latin America).

\subsection{Retreat from Globalization 1914-50: Raising New Policy Barriers}

As table 5.1 documents, the globalized world that fell apart after 1914 was not rebuilt during the interwar decades. Indeed, what distinguishes the interwar period is that globalization was dismantled solely by government policy. Governments imposed trade and factor market barriers where there were none before, and some even blocked communications. The interwar period was not marked by some disappearance of the previous nonpolicy sources of globalization. The big productivity gains in transportation and

18. There was, of course, mass migration within the poor periphery, even though economic historians have paid little attention to it. 
communications did not evaporate. Nor was there any collapse in world population growth - only new policy barriers imposed on poor populations that restricted their ability to flee miserable conditions for something better. The pace of technological progress may have slowed down, but, more importantly, the appearance of new disincentives reduced investment in the diffusion of modern technology around the world. In short, the interwar retreat from globalization was carried by antiglobal economic policies.

To judge what effect these antiglobal policies had on global inequality, let us begin with the overall trend in world inequality and then look at the role of policy in shaping that trend. Our expectations are to find symmetry between the pre-1914 and interwar periods. Thus, we expect to find the following: a convergence slowdown in the deglobalizing Atlantic economy (and perhaps even an acceleration in the rising trend in inequality gaps worldwide); an easement in the inequality forces operating within rich, labor-scarce economies; and an easement of the egalitarian forces operating within poor, labor-scarce economies.

\subsubsection{Between-Country Income Gaps 1914-50}

Figure 5.1 documents an interwar acceleration in the rising trend toward inequality between countries. In fact, over the almost two centuries documented by Bourguignon and Morrisson in that figure, there was no period when divergence between countries was more "big time." We do not yet know how much of this should be attributed to the Great Depression, two world wars, antiglobal policies, and other forces. However, there is plenty of evidence documenting that convergence stopped in the Atlantic economy before 1929 (Williamson 1996), when deglobalization was having an inegalitarian influence independent of war and depression. Migration barriers definitely widened international income gaps, and new barriers to trade and capital flows probably added to those widening gaps.

\subsubsection{Within-Country Inequality Trends 1914-50}

Figure 5.1 also shows that within-country inequality took a sharp nose dive between 1910 and 1950. This change is the most dramatic regime switch documented in the figure. While poor, labor-abundant OECD countries lost their pre-1914 egalitarian trends - some actually drifting toward greater inequality - the industrial European countries continued their egalitarian drift, and the rich, labor-scarce New World countries underwent egalitarian trends that were then called "revolutionary" (Lindert and Williamson 1985; Williamson 1997; Lindert 2000; Bourguignon and Morrisson 2002). True, deglobalization can hardly account for all of this worldwide within-country inequality nose dive; after all, those high pre-World War I within-country inequality levels were never recovered when globalization was reclaimed by the end of the twentieth century. The new barriers 
to migration must have raised inequality within sending countries and lowered it in receiving countries, ${ }^{19}$ reversing the prewar effects. Since the impact of new trade barriers on interwar within-country inequality has not yet been assessed, the overall effect of 1914-50 deglobalization on worldwide within-country inequality will have to await future research.

\subsection{Back on Track: The Second Globalization Boom}

Globalization by any definition resumed after World War II. It has differed from pre-1914 globalization in several ways. ${ }^{20}$ Factor migrations have been less impressive by most measures. The foreign-born are a smaller share of the total population than they were in the main Western Hemisphere receiving nations in 1913 (table 5.1), and capital exports were a smaller percentage of GDP in the postwar United States ( 0.5 percent in 1960-73 and 1.2 percent in 1989-96; Obstfeld and Taylor 1998, table 11.1) than they were in prewar Great Britain (4.6 percent in 1890-1913). On the other hand, trade barriers are probably lower today than they were in 1913 . These differences are tied to policy changes in one dominant nation, the United States, which has switched from a protectionist welcoming immigrants to a free trader restricting immigration. Another difference has already been revealed in figure 5.1: The postwar world started out much more unequal than the world of 1820 or 1870, and international income gaps, not income gaps within countries, now dominate the global inequality of living standards.

\subsubsection{International Gaps Again: An Epochal Turning Point?}

While the issues are elaborated in far greater detail by J. Bradford DeLong and Steve Dowrick in chapter 4 of this volume, we need to review here what has happened to between-country income gaps since 1950. Figure 5.1 uses data from Bourguignon and Morrisson (2002) to document what looks like a mid-twentieth-century turning point in their between-country inequality index, which slows its rise after 1950. However, the Bourguignon and Morrisson long-period database contains only fifteen countries. Using postwar purchasing-power-parity data for a much bigger sample of 115, Melchior, Telle, and Wiig $(2000,14)$ actually document a decline in their between-country inequality index in the second half of the twentieth century. The authors show stability in between-country inequality up to the late 1970s, followed by convergence centered on the early 1980s and early 1990s. Four other recent studies find the same fall in between-country inequality

19. This, after all, was one central motivation for the legislation that finally brought quotas to North America in the 1920s, after heated public debate over a quarter of a century (Goldin 1994; Timmer and Williamson 1998).

20. See Baldwin and Martin 1999; Bordo, Eichengreen, and Irwin 1999; Findlay and O'Rourke, ch. 1 in this volume; Chiswick and Hatton, ch. 2 in this volume; and section 5.3 in this chapter. 
after the early 1960s (Schultz 1998; Firebaugh 1999; Boltho and Toniolo 1999; Radetzki and Jonsson 2000). ${ }^{21}$ Among these five recent studies, perhaps most useful in identifying an epochal regime switch is that of Boltho and Toniolo (1999, plotted in Bourguinon and Morrisson, 2002, diagram 2.4 , p. 16), who show a rise in between-country inequality in the 1940 s, rough stability over the next three decades, and a significant fall after 1980, significant enough to make their between-country inequality index drop well below its 1950 level.

Did the postwar switch from autarky to global integration contribute to this epochal change in the evolution of international gaps in average incomes? Here we seek the answer focusing on trade, returning later to factor migration.

\subsubsection{Trade and Postwar Between-Country Inequality}

Conventional thinking presumes that liberalizing trade should have benefited third world countries more than it benefited leading industrial countries. The reasoning is the same as that already introduced when we surveyed pre-1914 experience. First, liberalizing trade should have a bigger effect on the terms of trade of the country joining the larger integrated world economy than on countries already integrated. Second, the more a country's terms of trade are changed, the bigger the gain in national income. ${ }^{22}$

In one simple respect, the gains from postwar liberalization should have been greater among the high-income OECD countries than among poorer countries as a whole. The postwar trade that was liberalized the most was in fact intra-OECD trade, not trade between the OECD and the rest. From the very beginning in the 1940s, the General Agreement on Tariffs and Trade (GATT) explicitly excused low-income countries from the need to dismantle their import barriers and exchange controls. This permission probably lowered their national incomes, but it was consistent with the dominant protectionist and antiglobal ideology prevailing in emerging nations at that time. Thus, the succeeding rounds of liberalization under GATT, from the Dillon and Kennedy Rounds through the Uruguay Round, brought freer trade and higher incomes mainly to OECD members. We emphasize again

21. They all use purchasing power parity data for which the fall is far clearer. Indeed, it disappears in studies that use income data in U.S. dollars (Melchior, Telle, and Wiig 2000, diagram 2.4, p. 16). See also Dowrick and DeLong, chap. 4 in this volume.

22. As we noted for the 1820-1913 era, poor-country gains from trade depend on whether expanding before 1914 may have induced deindustrialization in poorer countries. Did the same happen after World War II? Probably not. After all, industrial manufactures have been a rapidly rising share of third world output and exports. For example, for all "developing" (third world) countries, manufactures rose from only 17.4 percent of commodity exports in 1970 to 64.3 percent by 1994 (United Nations Conference on Trade and Development 1988 and 1997). Enough of the third world is now labor-abundant and natural-resource-scarce so that the growth of trade has helped it industrialize. The classic image of third world specialization in primary products is becoming obsolete. 
that these facts do not show that globalization favors rich participants. Rather, globalization favors all participants who liberalize, especially those who are newly industrializing, and penalizes those who choose not to liberalize, leaving them behind.

The abundant literature on trade liberalization in the third world is, unfortunately, limited to analysis of the effects of one country's liberalization on its own income and ignores effects on the rest of the world. This limitation may be innocuous for small countries, but it is a serious omission for the giants. Thus, we have only assessments of China's liberalization on China, not of China's liberalization on the world. The same is true of the United States, the European Union, the Russian Federation, and other giants. Still, this literature does yield fairly firm conclusions about whether liberalizing countries gain from freer trade.

Four kinds of studies have tried to judge the gains from freer trade, or the losses from more protection, in the developing countries. Led by a large National Bureau of Economic Research (NBER) project on trade and exchange-control regimes in the 1960s and 1970s, economists explored the sectoral connections between protection and growth in fourteen developing countries. To quantify the overall effects of complicated trade regimes, the authors resorted to classic partial-equilibrium calculations of deadweight costs. ${ }^{23}$ They concluded that the barriers imposed significant costs on Argentina, Chile, Colombia, Egypt, Ghana, India, Israel, Mexico, Pakistan, the Philippines, South Korea, Taiwan, and Turkey. ${ }^{24}$ By themselves, these standard welfare calculations are vulnerable to the charge of assuming, not proving, that trade barriers were bad for these developing countries. Such calculations assume that all the relevant effects are captured by measures of consumer and producer surplus, without allowing protection any chance to lower long-run cost curves, as it is assumed to do in the traditional infantindustry case, and to foster industrialization and thus growth, as in those modern growth models where industry is the carrier of technological change and capital deepening. Thus, it would be fair to demand more proof than that offered by the comparative static calculations of the 1960s and 1970s.

A second kind of evidence consists of cross-country growth studies that contrast the growth performance of relatively open and closed economies. The World Bank conducted such studies for forty-one countries in the periods before and after the first oil shock. Table 5.3 extends this coverage through 1992. The correlation between trade openness and growth seems clear enough in this demonstration, but the correlation is vulnerable to two criticisms. First, assigning countries to trade policy categories is always tricky, since it is hard to measure overall openness. Second, and much more importantly, it is hard to isolate the effect of trade policies alone, since other

23. Bhagwati and Krueger (1973-76). See also Balassa (1971) and Papageorgiou, Michaely, and Choksi (1991).

24. Only in Malaysia did the import barriers yield a slight gain, and that was because of favorable terms-of-trade effects. 
Trade Policy Orientation and Growth Rates in the Third World, 1963-92

\begin{tabular}{lccc}
\hline & \multicolumn{3}{c}{$\begin{array}{c}\text { Average Annual Growth Rates of } \\
\text { GDP Per Capita (\%) }\end{array}$} \\
\cline { 2 - 4 } Orientation & $1963-73$ & $1973-85$ & $1980-92$ \\
\hline Strongly open to trade & 6.9 & 5.9 & 6.4 \\
Moderately open & 4.9 & 1.6 & 2.3 \\
Moderately antitrade & 4.0 & 1.7 & -0.2 \\
Strongly antitrade & 1.6 & -0.1 & -0.4 \\
\hline
\end{tabular}

Sources: World Bank (1987, 78-94), with further growth data from World Bank 1994.

Notes: In all periods the three strongly open economies were Hong Kong, South Korea, and Singapore. The identities of the strongly antitrade countries changed over time. In 1963-73, they consisted of Argentina, Bangladesh, Burundi, Chile, the Dominican Republic, Ethiopia, Ghana, India, Pakistan, Peru, Sri Lanka, Sudan, Tanzania, Turkey, Uruguay, and Zambia. For the two overlapping later periods the strongly antitrade group consisted of the previous sixteen plus Bolivia, Madagascar, and Nigeria, but minus Chile, Pakistan, Sri Lanka, Turkey, and Uruguay. For the identities of the moderate-policy groups, see World Bank (1987, 78-94).

policies are usually changing at the same time. Liberalism typically comes as a package. Thus, countries that liberalized their trade also liberalized their domestic factor markets, liberalized their domestic commodity markets, and set up better property-rights enforcement..$^{25}$ The appearance of these non-trade policies may deserve more credit for raising income than the simultaneous appearance of more liberal trade policies.

A third kind of evidence comes from event studies. Here the strategy is to focus on periods when trade policy changed the most so as to see its effect on growth. For example, Krueger $(1983,1984)$ looked at trade-opening moments in South Korea around 1960, Brazil and Colombia around 1965, and Tunisia around 1970. Growth improved after liberalization in all four cases (Krueger 1983, 1984). More recently, Dollar and Kraay (2000b) examined the reforms and trade liberalizations of sixteen countries in the 1980s and 1990s, finding, once again, the positive correlation between freer trade and faster growth. Here, too, critics could argue that the reform episodes changed more than just participation in the global economy, so that an independent trade effect has not been isolated.

Finally, recent studies have used multivariate econometric analysis in an attempt to resolve the doubts left by simpler historical correlations. The number of national experiences analyzed statistically now numbers in the hundreds (Edwards 1992, 1993; Dollar 1992; Dollar and Kraay 2000a, b.) Even with several other variables held constant, those studies show that freer trade policies tend to have a positive effect on growth, although one cannot statistically reject a zero effect in many of the tests. These econometric studies have raised the scientific standard of inquiry about the effects

25. This was true, for example, in Great Britain, where the 1846 repeal of the Corn Laws was immersed in a deluge of domestic liberal reform. 
of trade policy, although critics are free to raise their standards too, retaining doubts about omitted variables, simultaneity, and details of the error term in each econometric equation. And economic historians might argue that it depends on when a country goes global: Are its trading partners liberalizing too? Are its competitors liberalizing? Is the liberalizing country ready for industrialization, accumulation, and human capital deepening, or will it be driven instead up some primary-product-producing dead end? It might be argued that conditions were less auspicious for third world liberalization in 1870-1914 or 1914-60 than since 1960, or, as we shall see, in the 1980s and 1990s compared with the 1960s and 1970s.

The doubts that each individual study might raise threaten to block our view of the overall forest of evidence. Even though no one study can establish that trade openness has unambiguously helped the representative third world economy, the preponderance of evidence does seem to support this conclusion. One way to see the whole forest more clearly is to consider two sets, one almost empty and one completely empty. The almost-empty set consists of all statistical studies showing that protection helps third world economic growth or that liberalization harms it. The set would have been completely empty had not Bairoch $(1972,1989)$ and O'Rourke (2000) both found that protectionist countries grew faster before 1914. Thus, their findings suggest a paradox: Although the protection-growth correlation was negative after 1950, it was positive before 1914. True, Bairoch and O'Rourke did not evaluate third world countries, since their samples included only a few members of the Atlantic economy club. However, they get support from Clemens and Williamson (2001), who have recently shown that the positive protection-growth pre-1914 paradox holds for a much bigger world sample, and even holds through the late 1920s, but the correlation is far weaker and often negative for the European and the third world periphery. Clemens and Williamson also show how the world trade environment accounts for the pre-1914 versus post-1950 contrast. The negative (positive) correlation between openness (protection) and growth before 1914 is also consistent with the recent finding by Hadass and Williamson (2001) that terms-of-trade improvements associated with globalization reduced long-run income growth between 1870 and 1940 in the periphery while raising it in the center. The fact that this set is almost but not completely empty raises a challenge; observers will have to deal with the historical paradox in future work.

The second, and this time empty, set contains those countries that chose to be less open to trade and factor flows in the 1990s than in the 1960s and rose in the global living-standard ranks at the same time. As far as we can tell, there are no antiglobal victories to report for the postwar third world. ${ }^{26}$

26. Going back further to 1928 would, however, capture the Soviet Union, a country that took off while deglobalizing. Emerging nations in Asia, Africa, and Latin America certainly saw this as an antiglobal victory, but Stalin might have done far better had he stayed open. 
We infer that this is because freer trade stimulates growth in the third world today, regardless of its effects before $1940 .^{27}$

Timing matters, and, in retrospect, we think we can detect a hidden source of East Asian super-growth by appealing to it. Other countries may have given the East Asians their chance by failing to compete in laborintensive manufacturing export markets and make market reforms, long before the 1980s. Thus, the original Four Tigers - Singapore, South Korea, Taiwan, and Hong Kong - probably owe much of their export-led success in the 1960s and 1970s to the protectionist and illiberal domestic policies of mainland China, North Korea, Vietnam, Burma, Bangladesh, India, and Pakistan. In the 1980s a newly opened China began to catch up, perhaps partly because India and the others remained so antitrade. ${ }^{28}$

\section{Trade and Inequality within Postwar Third World Countries}

Although removing barriers to trade may raise per capita income in developing countries, what does it do to inequality within them? The simple Stolper-Samuelson model, as we have noted, would predict that freer trade would be egalitarian for these countries, since it allows those abundant in unskilled labor to shift toward unskilled-labor-intensive production, raising unskilled wages relative to skilled wages and returns on property. Has this been true?

The effect of globalization on inequality within third world countries is just as hard to chart for the postwar era as it is for the pre-1914 era. The postwar data are still sparse, and they are available for only a few countries. Fortunately, we can get a good idea of the overall effect on within-country inequality just by following the experience of a few giants neglected by the literature, but we start with the smaller countries that have been studied in far greater detail.

Some Latin and Asian Experience. The recent literature on globalization and inequality within developing countries since the 1960 s has a pretty narrow focus. It has concentrated on nine countries - six Latins (Argentina, Chile, Colombia, Costa Rica, Mexico, and Uruguay) and three East Asians (Korea, Singapore, and Taiwan). In order to test the Stolper-Samuelson prediction, the recent literature has dwelt on the pay gaps between skilled and unskilled workers.

This recent assessment of the globalization and inequality connection in

27. As economic historians, we want to know whether what is true now was true a century ago, and if not, why not. Has a shift toward benefiting from trade been due to a century of faster population growth in the third world, which has shifted its comparative advantage toward labor-intensive manufactures and away from resource-intensive primary products? To what extent is this shift just a reflection of the opening up of labor-abundant and resourcescarce Japan, Korea, and China to world trade? These issues are on the research agenda.

28. The experiences of Thailand, Malaysia, and Indonesia are consistent with this conjecture because these three countries were intermediate in all respects - in both the levels and the rates of change in their trade barriers and their incomes. 
developing countries diverges sharply between regions and epochs. Wage gaps seemed to fall when the three Asian tigers liberalized in the 1960s and early 1970s. Yet wage gaps generally widened when the six Latin American countries liberalized after the late 1970s (Wood 1994, 1997, 1998; Feenstra and Hanson 1997; Robbins 1997; Robbins and Gindling 1999; Hanson and Harrison 1999). Why the difference?

As Wood (1997) has rightly pointed out, historical context was important, since other things were not equal during these liberalizations. The clearest example in which a Latin wage widening appears to refute the egalitarian Stolper-Samuelson prediction was the Mexican liberalization under Salinas in 1985-90. Yet this liberalization move coincided with the major entry of China and other Asian exporters into world markets. Thus, Mexico faced intense new competition from less skill-intensive manufactures in all export markets. ${ }^{29}$ Furthermore, blue-collar wage rates were already higher in Mexico than in many Asian countries, suggesting that the widening of Mexican pay gaps in 1985-90 actually fits the Stolper-Samuelson prediction because at that point Mexico was a high-wage country in the relevant world export markets.

Historical context could also explain why trade liberalization coincided with wage widening in the five other Latin countries, and why it coincided with wage narrowing in East Asia in the 1960s and early 1970s. Again, timing matters. Competition from other low-wage countries was far less intense when the Asian tigers pulled down their barriers in the 1960s and early 1970s compared with the late 1970s and early 1980s when the Latin Americans opened up. In addition, trade liberalization in Argentina 1976-82 was accompanied by union-busting and an easing of minimum-wage controls. The same policies were carried out with an even firmer hand in Pinochet's Chile 1974-79, another documented case of wage widening coinciding with trade liberalization. In these cases, at least, wages may have widened for reasons other than the liberalization of international trade and foreign investment.

The Experience of the Giants. Past evidence on the wage-inequality and trade-liberalization connection in developing countries has been decidedly mixed. ${ }^{30}$ But even if the findings from the usually studied developing countries were not mixed, they could not have had much of an impact on global inequalities. After all, the half-dozen Latin countries, plus the three Asian tigers, are tiny relative to four huge countries that have undergone even larger policy shocks. Specifically, the literature has focused on nine countries

29. It might also be relevant to point out that Mexico's own import liberalization brought much greater tariff reductions on low-skill manufactures than on high-skill manufactures.

30. One other indicator, however, may tip the scale toward the belief that globalization widens pay gaps in developing countries: Latin American employees of multinational firms and international joint ventures receive higher wages, with or without adjustment for skills and other factors (Aitken, Harrison, and Lipsey 1996; Pavcnik 2000). 
that together had less than 200 million people in 1980, whereas China by itself had 980 million, India 687 million, Indonesia 148 million, and Russia 139 million. All four of these giants recorded widening income gaps after their economies liberalized. The widening did not start in China until after 1984, because the initial reforms were rural and agricultural and therefore had an egalitarian effect. After the reforms reached the urban-industrial sector in 1984, China's income gaps widened (Griffin and Zhao 1993, especially p. 61; Atinc 1997; World Bank 1993-2000/1; Chowdhury, Harvie, and Levy 2000). India's inequality has risen since liberalization started in the early 1990s. Indonesian incomes became increasingly concentrated in the top decile from the 1970s to the 1990s, although this probably owed more to the Suharto regime's ownership of the new oil wealth than to any conventional trade-liberalization effect. Russian inequalities soared after the collapse of the Soviet regime in 1991 (Flemming and Micklewright 2000).

Income widening in these four giants dominates global trends in intranational inequalities, ${ }^{31}$ but how much was due to liberal trade policy and globalization? Probably very little. Indeed, much of the inequality surge during their liberalization experiments seems linked to the fact that the opening to trade and foreign investment was incomplete. That is, the rise in inequality appears to have been based on the exclusion of much of the population from the benefits of globalization.

China, where the gains since 1984 have been heavily concentrated in the coastal cities and provinces (Griffin and Zhao 1993; Atinc 1997), offers a good example. Migration from the hinterland to the cities was pretty much prohibited before the mid-1990s. Those that were able to participate in the new, globally linked economy prospered faster than ever before, while the rest in the hinterland were left behind, or at least enjoyed less economic success. China's inequality had risen to American levels by 1995 (a Gini of .406), but the pronounced surge in inequality from 1984 to 1995 was dominated by the rise in urban-rural and coastal-hinterland gaps, not by widening gaps within any given locale. This pattern suggests that China's inequality has been raised by differential access to the benefits of the new economy, not by widening gaps among those who participate in it, or among those who do not. ${ }^{32}$

31. The giants also dominate trends in between-country inequality. Much of the fall in the between-country inequality index offered by Melchior, Telle, and Wiig $(2000,15)$ is due to the fact that the populations in Japan and the United States are getting relatively fewer and less rich, while those in China and India are getting richer and more populous.

32. In Russia, the benefits were also skewed toward those who were able to participate in the reforms and internationalization, although for a different reason. The handing over of state trading prerogatives and physical assets to a few oligarchs contributed to one of the greatest inequality surges in history (Flemming and Micklewright 2000). Similarly, the assets of the Suharto family and its cronies in Indonesia tended to be concentrated in the expanding trade sector. More comprehensive and competitive access to the international economy might have brought a more egalitarian result in each of these cases. 
Multinationals, Sweatshops, and Children. One theme that has dominated recent news coverage about global interactions and global inequality is the imagined association of multinational enterprise with harsh "sweatshop" labor conditions and the use of child labor in the third world. The imagery is familiar: Pakistani boys sew soccer balls, Chinese women make Kathie Lee wardrobe items, and Indonesians make Nike running shoes, all far into the night. Do such interactions widen the income gaps between rich and poor countries? Do they benefit only the multinational firms that employ cheap third world labor? ${ }^{33}$

Two issues of global concern overlap here. One is the extent to which employers violate International Labor Organization (ILO) codes and labor standards regarding fair labor contracts and exploit both adults and children. The other is whether the employment of third world children is at the expense of their schooling, their best investment for the long run. Both are legitimate concerns. The first calls for international and national monitoring to enforce legal codes, although the codes themselves have been vague, perhaps necessarily so (Brown 2001). The second calls for pressure on governments to supply tax-based schooling, as all industrialized countries did when launching primary education in the nineteenth century (Lindert 2001). Both are complex issues, and the relevant theory and evidence are still just emerging (U.S. Department of Labor, Bureau of International Affairs 1995-2000; Basu 1999).

As far as one can tell from partial evidence, however, neither of these potential evils is connected with globalization. The employment of children or other unskilled labor by multinational firms probably reduces those wide income gaps between countries. After all, there is no positive correlation between nonagricultural international exchange and the use of child laboreither over time, or across countries, or across sectors of any economy. During the globalizing half-century since 1950, the rates of work by children under fifteen have been declining in every ILO country, and school enrollment rates have been rising (Brown 2001). The rates of work and nonschooling are lowest in the most internationally involved countries. The most visible recent case of a country's suddenly joining the international economy is China, where the rate of decline in child labor has been faster since 1980 than in the rest of the third world, and faster than it was previously under Chairman Mao. And across sectors of China's economy, the highly publicized manufacturing-export sector has a rate of child employment that is well below the national average. The multinationals hire more skilled, and more schooled, labor than the national average.

33. For a typical recent presentation of prima facie evidence of labor abuse involving manufacturing exports from the Third World, see Bernstein, Shari, and Malkin (2000). For a longer presentation of the imagery, see Greider (1997). The social reform literature on child labor in British cities during the first industrial revolution reads pretty much the same way, but some say abuse was minor (Nardinelli 1990) whereas others say it was major (Tuttle 1999). 
Would a ban on the use of child labor in globally connected activities send third world children back to school? As Basu (1999) has pointed out, a ban targeted at child labor in manufacturing export sectors would probably send children back to agriculture, where they work the most and attend school the least. It is difficult to see how future third world generations would catch up with the high-income world any faster if there were bans on the export of manufactures that use child labor. Where third world paths to school and faster income growth seem blocked, they are not blocked by employment opportunities in the modern export sector. Instead, they are blocked by the lack of national political resolve to raise tax support for schools.

\section{What Role for Globalization in OECD Wage Inequality since the 1970s?}

The best-documented and most heatedly debated experience linking globalization with inequality is the recent OECD wage widening, especially within the United States and the United Kingdom. An enormous amount of recent research now gives us a pretty clear idea of the share of rising inequality that should be attributed to an increase in international integration.

How Wage Gaps Moved. The trend toward wider wage gaps in America and Great Britain was unmistakable in the 1980s and early 1990s, as illustrated in figure 5.6. It showed up in ratios of the 90th percentile full-time wage to the 50th or 10th percentile full-time wage, either for men or for women. In the United States, a rise also took place in the full-time pay ratios of college graduates to high school graduates, and in the pay ratio of nonproduction employees to production employees. The widening has been severe enough

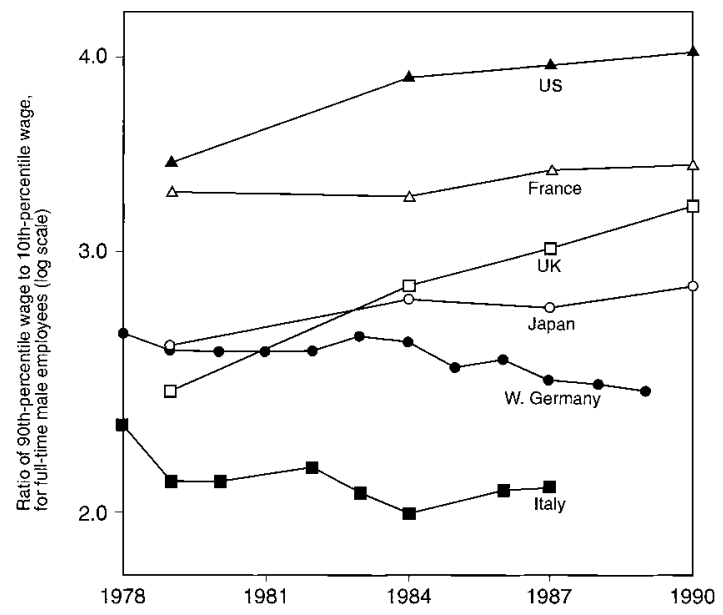

Fig. 5.6 Inequality of full-time earnings of male employees in six countries, 197890 
that lower-skilled groups had no gain, and probably a slight loss, in real pay over the whole quarter-century 1973-98, despite a healthy growth of real earnings for the labor force as a whole. ${ }^{34}$

Other OECD countries probably also experienced pay widening across the 1980s, although different measures tell different stories. Sticking with full-time labor earnings, one cannot find much widening at all for France or Japan, and none for Germany or Italy, as in figure 5.6. Yet income measures that take work hours and unemployment into account reveal some widening even in those cases. A recent OECD study surveyed the inequality of disposable household income from the mid-1970s to the mid-1990s (Burniaux et al. 1998, tables 2.1, 2.2, and 3.1-4.9). Between the mid-1970s and the mid-1980s, the Americans and British were alone in having a clear rise in inequality. From the mid-1980s to the mid-1990s, however, twenty out of twenty-one OECD countries had a noticeable rise in inequality. Furthermore, the main source of rising income inequality after the mid-1980s was the widening of labor earnings. The fact that labor earnings became more unequal in most OECD countries, when full-time labor earnings did not, suggests that many countries took their inequality in the form of more unemployment and hours reduction, a well-documented tendency for Western Europe in those years.

What Widened American Wage Gaps? The recent American wage widening has generated an energetic search for its sources, and they are of two sorts. First, there are aspects of globalization: the rise in unskilled worker immigration rates, due to rising foreign immigrant supply or a liberalization of U.S. immigration policy (or both). Increased competition from imports that use unskilled labor more intensively than the rest of the economy must be added to the immigration impact. This increased competition is due to foreign supply improvements, including that carried by U.S. outsourcing; international transportation improvements; and trade-liberalizing policies. Second, there are those sources apparently unrelated to globalization, including a slowdown in the growth of labor-force skills; a weakening of labor unions, which have long lobbied for flatter pay scales; and biased technological change that cuts the demand for unskilled workers relative to skilled workers.

Most contributions to the debate have had a narrower focus than the previous summary would suggest. They have retreated to judging a "trade versus technology" contest, ignoring the possible roles of unions, immigration, and skills or schooling supply. ${ }^{35}$ Some agree with $\operatorname{Wood}(1994,1998)$ that

34. The assertion about absolute living standards awaits the results of debate about exaggerated measurement of cost-of-living increases over the same period in the United States (Boskin et al. 1998).

35. For a survey of the whole literature up through 1996, see Cline (1997, especially table 2.3 and the surrounding text). For a more up-to-date survey, with deeper coverage of certain econometric issues, see the volume edited by Feenstra (2000), particularly the editor's introduction and the contributions by Slaughter (2000) and Harrigan (2000) in that volume. 
trade is to blame for much of the observed wage widening. Others reject this conclusion, arguing that most or all of the widening is due to a shift in technology that has been strongly biased in favor of higher-skill occupational groups (Lawrence and Slaughter 1993; Berman, Bound, and Griliches 1994). Most estimates tend to resemble the guess by Feenstra and Hanson (1999) that perhaps $15-33$ percent of the rising inequality is due to trade competition, including outsourcing.

Nonspecialists observing this debate need to pay close attention to how the participants deal with a fundamental endogeneity issue. Are globalization and technology change independent, or does one drive the other? Those inclined to absolve globalization point out that the rise of imports, and the decline of import-competing jobs, is often a by-product of healthy growth, both in the OECD and the third world exporters. To these participants, technological change drives globalization. Two examples taken from the debate illustrate the opposing view. Feenstra and Hanson (1999) argue that skill-saving technological bias within the United States is a by-product of the global communications revolution that allows better monitoring of foreign production and just-in-time inventory delivery from abroad. Thus, Lawrence (2000) argues that rising import competition deserves credit for much of America's technological progress. To these participants, globalization drives technological change.

The boldest attempt at an overall quantitative accounting of these potential sources is the appraisal by Cline (1997). Cline's interpretation of his estimates differs from ours. Cline blames globalization less than do most writers on the subject, and he emerges with a huge 58 percent unexplained residual. In a summary table (1997, table 5.1), Cline suggests that about half of this residual was due to skill-biased technological change, and the resulting 29 percent technology effect is bigger than any globalization effect. However, there is a second way to read Cline's table. His nonglobalization sources appear to almost balance out $(1.58 \times .65=1.03$, or only 3 percentage points), whereas his globalization forces could explain almost all the wage-gap widening (16 out of 18 percentage points). The proper question, typically left unasked, is how the period 1973-93 differed from the one that preceded it, 1953-73. If the other sources added up to pretty much the same impact in the first two-decade period, then it would be the change in globalization forces between the two periods that mattered.

Broader Perspectives. Although the recent exploration of the determinants of American wage inequality has established fairly firm results, the debate is still too narrow to judge the full impact of globalization on inequality within the industrial OECD. Several extensions are needed before the evidence can be said to have dealt with the big questions that sparked the debate. One extension would be in the direction of more evidence, whereas another would be in the direction of more comprehensive measures.

Regarding the use of more evidence, note that the literature has thrown 
away information by confining itself to the era of widening wage gaps since about 1980. After all, when the world economy became increasingly integrated in the century or two before 1980, technology also had its factor biases, and the mismatch between technological bias and skills growth kept shifting (Williamson and Lindert 1980; Goldin and Katz 1999, 2000). Why the inequality booms and busts in America over the past century or two? Any attempt to distill the effects of globalization on inequality needs to answer that question. Furthermore, the literature is dominated excessively by American experience, so we need more economic histories to right the balance. After all, while recent inequality rose just as steeply in Great Britain, the steepness of the rise varied a great deal across the OECD. ${ }^{36}$ Why?

Confining our view to employee earnings has also denied us extra perspective on both the scope and the source of the rise in inequality. What happened to self-employment income, property income, profits, and executive compensation? ${ }^{37}$

Regarding the use of measurement, note that any force that creates more within-country inequality is automatically blunted today-at least in the OECD, a point that is rarely noted in the inequality debate. Any rise in household net disposable post-fisc income inequality will always be less than the rise in gross nominal pre-fisc income inequality. Tax-and-transfer systems guarantee this result in the OECD. Any damage to the earnings of low-skilled workers is partially offset by their lower tax payments and higher transfer receipts, like unemployment compensation or family assistance. This broadening of income concept therefore serves to shrink any apparent impact of globalization on the inequality of living standards. ${ }^{38}$

Does globalization destroy these automatic stabilizers by undermining

36. Several contributions in the Freeman-Katz volume (1995) do compare explanations of inequality in the United States versus other countries. However, the focus is on the technologyskill demand-inequality connection, with almost no attention to possible globalization-skill demand-inequality connections.

37. Granted, Burniaux and coauthors (1998) did report changes in overall income inequality for several OECD countries, but they did not attempt to assess competing explanations. One tantalizing clue that some stories at the top of the income range have been overlooked comes from recent international comparisons of the compensation of chief executive officers (CEOs; Crystal 1993; Abowd and Bognanno 1995). The level of CEO compensation is far higher in the United States than in other countries, not only in real purchasing power but also in ratio of their pay to that of ordinary production workers. Did the fact that this CEO pay advantage rose from the late 1980s to the early 1990s have anything to do with outsourcing, direct foreign investment, and other dimensions of globalization? The link is certainly not obvious. International differences in CEO compensation seem to be unrelated to performance, since U.S. firms under attack from foreign competition maintained much higher CEO compensation than did their successful foreign competitors. This puzzle should be linked to the competing theories of the determinants of intranational inequality in the OECD.

38. Although this statement certainly applies today, it did not apply to the first globalization boom before World War I, when such safety nets were not yet in place. Similarly, it will not apply to any emerging nations where modern safety nets are not yet in place. 
taxes and social transfer programs? In a world where businesses and skilled personnel can flee taxes they dislike, there is the well-known danger of a "race to the bottom," in which governments compete for internationally mobile factors by cutting tax rates and therefore cutting social spending. As Rodrik (1997) has stressed, however, the relationship between a country's vulnerability to international markets and the size of its tax-based social programs is positive, not negative, as a race to the bottom would imply. Thus, countries with greater vulnerability to global market changes have higher taxes, more social spending, and broader safety nets. Although there may be other reasons for this positive raw correlation between openness and social programs, there is no apparent tendency for globalization to undermine the safety nets.

\section{Postwar International Investment: How Inegalitarian Could It Be?}

The fear that globalization is widening world gaps between rich and poor stems in part from the belief that investors in the rich countries are reaping all the gains from international investment in the poor countries. These fears cannot be allayed solely by reference to competitive-market models, since these fears come from those who do not believe such models. As an alternative demonstration, we can show that the size of such investment income - interest, dividends, repatriated profits, royalties, and fees - is much too small to account for the global inequalities we observe.

Two pessimistic assumptions will set an upper bound on the extent to which returns on international investment could have widened world inequality. First, suppose nobody else in the world gains from these investments, so that these rich investors and patent holders are able to collect all of the returns on them, thus increasing their shares of world income and world inequality. Alternatively, suppose international investment is a zerosum game, so that the amounts gained by the rich international investors are matched by an equal loss to somebody in the host countries.

Table 5.4 shows that earnings on international investments and technology could not be big enough to explain the global inequalities we see, regardless of which extreme assumption one chooses. There are three parts: The top one (part A) shows what is to be explained, the rise in the share of the world's income held by the rich, from 1820 and from 1970; the middle (part B) assesses the role of returns on international investment under those two assumptions. The extreme assumption that only the richest are affected (discussed in part C) leads to the conclusion that investments by five leading investor countries (Germany, Japan, the Netherlands, the United Kingdom, and the United States) in all foreign countries (part B, columns [1] and [2]) have not been big enough to explain even a third of the rise in world inequality since 1970 . The extreme assumption that the host countries actually lose as much as the international investors gain does not magnify the 
Table 5.4

Worst-case Globalization: Overestimates of the Impact of International Investments on Global Income Inequality

A. Net changes up to 1992, as percent of world income

\begin{tabular}{lcc}
\hline & Since 1820 & Since 1970 \\
\hline Top 5\% of world incomes & +3.8 & +1.6 \\
Top 10\% of world incomes & +10.3 & +2.5 \\
Top 20\% of world incomes & +15.6 & +2.4 \\
\cline { 2 - 3 } & &
\end{tabular}

B. Private investment incomes, as percent of world income

\begin{tabular}{ccccc}
\hline \multicolumn{2}{c}{$\begin{array}{c}\text { On Investments in All } \\
\text { Foreign Countries }\end{array}$} & & \multicolumn{2}{c}{$\begin{array}{c}\text { On Investment in Third } \\
\text { World Countries }\end{array}$} \\
\cline { 5 - 6 } Since 1820 & Since 1970 & & Since 1820 & Since 1970 \\
\hline 0.42 & 0.18 & & 0.13 & 0.03 \\
1.72 & 0.50 & & & \\
\hline
\end{tabular}

C. Maximum impacts on global inequality?

Contrast the historical inequality-related income shifts to be explained (part A, above) with these incomes involved in international investments up to 1992 (part B). Assuming that international investment benefits only the investors and that nobody loses income would suggest using columns (1) and (2) in part B as gains within the top 5 percent of the world income ranks. However, assuming this implies little pessimism about investment globalization, since nobody is hurt.

Using the zero-sum assumption that the investments hurt the host countries as much as they help investors would cancel most of the effect on inequality, since the host countries are usually as rich as the investing countries. Applying this pessimistic zero-sum assumption only to columns (3) and (4), the third world investment, gives tiny effects like those shown for the U.S. investments.

Sources: The changes in top-group shares of world income are from Bourguignon and Morrisson (2002, table 1). The changes in U.S. private investment income in foreign countries, including royalties and fees, are from U.S. Bureau of Economic Analysis, Survey of Current Business, various issues. The rough estimate for five leading countries magnifies the U.S. factor incomes by the relative total (not just private investment) factor-income earnings given by IMF, International Financial Statistics Yearbook, for the five leading countries chosen here: Germany, Japan, the Netherlands, the United Kingdom, and the United States.

modest effect on inequality, but rather reduces it. The reason is that the host countries are typically as rich as the investors' home countries. In fact, the world's largest net borrower since 1980 has been the United States. The zero-sum assumption therefore actually yields less impact on global inequality than the nobody-is-hurt-abroad assumption, since the supposed losses accrue to people near the top of the world income distribution. The net effect on global inequality in this case must be practically zero. To sustain pessimism, critics might want our zero-sum assumption to apply only 
to investments in the third world, where they are exploitative enough to be zero-sum for the world. Yet, as table 5.4 (part B) shows for American investments in the third world, these magnitudes are tiny in relation to global income and tiny in relation to the net changes to be explained in the top panel. Even if the impact of other leading investing countries is added, the basic point remains: International investment cannot account for much of the observed global inequalities in our modern world, even under extreme assumptions.

\subsection{Adding Up the Effects of Globalization}

\subsubsection{Sources of World Inequality 1500-2000: The Big Picture}

Some patterns have emerged through the complexity of history that suggest a tentative answer to the question posed by this essay's title: Does globalization make the world more unequal? The patterns cluster around two observations. One is that the gainers from globalization were never all rich and the losers were never all poor, or vice versa. The other is that participants in globalization pulled ahead of nonparticipants. This was true both for excluded or nonparticipating groups within countries as well as for excluded or nonparticipating countries.

How these patterns emerge from five centuries of diverging world incomes and a shorter period of globalization is summarized in table 5.5. The overall trends to be explained are those introduced in figure 5.1. World income inequality has risen since 1820 , and probably since the sixteenth century. Most of that increased world inequality took the form of a rise in income gaps between nations, not of a rise in within-country inequality. However, the gaps between nations were not widened by participation in globalization. As for the visible inequalities within countries, the effects differed by region and by historical era. Before World War I, globalization raised inequality within the United States and other New World countries, but it had the opposite effect in those European countries that were committed to trade and sent out emigrants. After World War II, globalization once again widened inequality within the United States and perhaps other OECD countries. Globalization may also have raised inequality in the newly trading and industrializing countries, such as the Asian tigers, China, Mexico, and Brazil. Yet the rising inequality in these countries was not evident among persons and households in the newly trading regions and sectors. Rather, it took the form of widening gaps between them and the less prosperous, nonparticipating regions. The poorest regions and the poorest countries were probably not hurt by globalization; they just failed to be part of it. Where the nonparticipants were actively excluded, the policies yielding that inegalitarian result can hardly be called liberal, but globalization cannot be made to take the blame. 


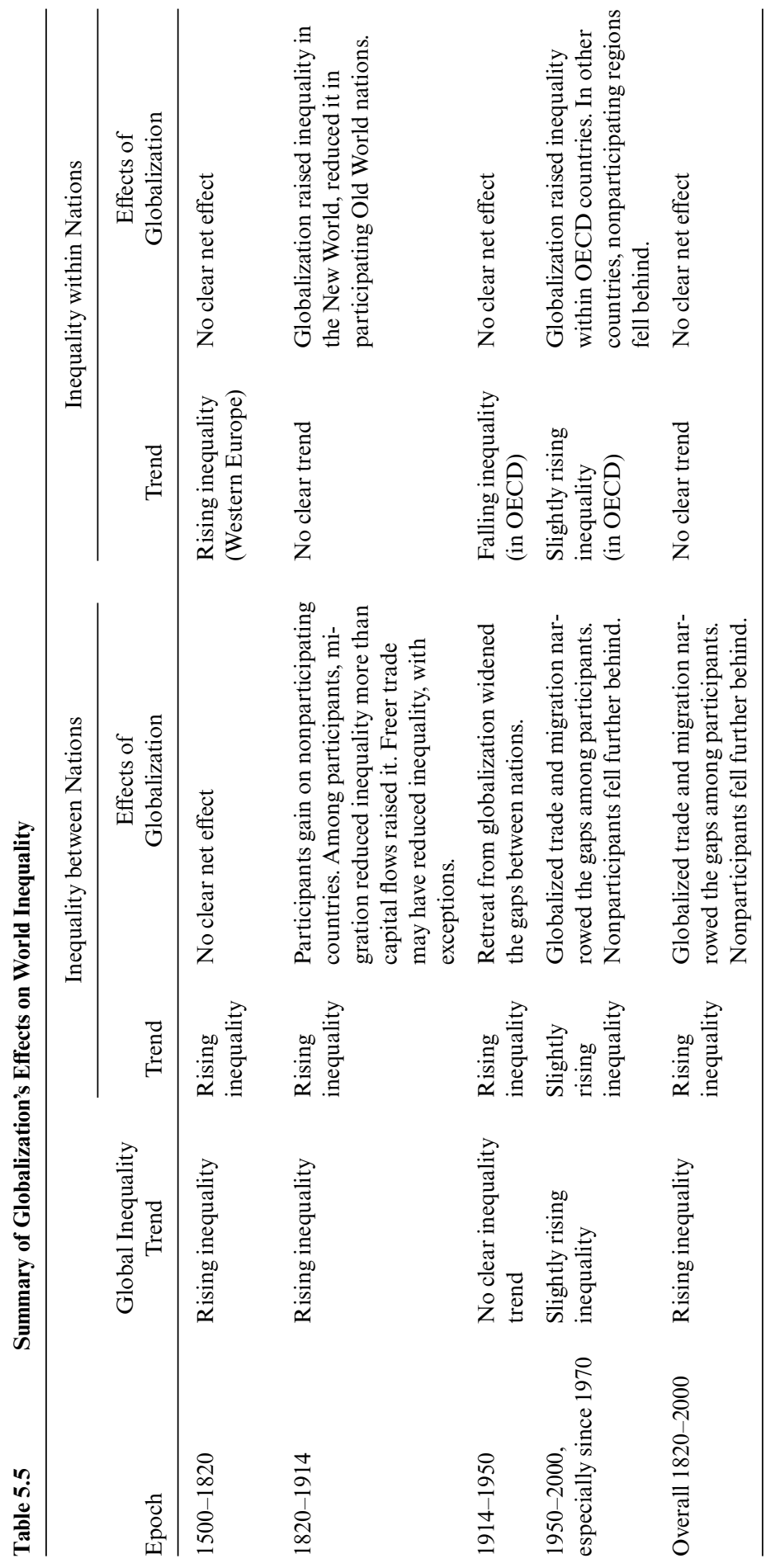




\subsubsection{How Unequal Would a Fully Integrated World Economy Be?}

What if we had a huge world economy, even bigger than the world economy back at the mid-twentieth century, ${ }^{39}$ with a unified currency and only negligible barriers to trade, migration, and capital movements? Would such an economy be more unequal than the world of today?

We have good examples today of huge integrated economies, at least as big as the world economy in 1950. One obvious example is the United States. Japan is another, and the European Union is moving toward becoming the third giant integrated economy. How unequal are incomes within these already globalized economies? Less unequal than in today's only partly globalized world economy, where the Gini coefficient of inequality in income per capita at international (purchasing power parity) prices in 1992 was $.663 .^{40}$ The Gini for the more integrated U.S. economy, by contrast, was only .408 in 1997, and that for Japan was only .249. There is nothing inherently less egalitarian about a large integrated economy compared with our barrier-filled world.

One might still fear that a truly globalized world would have vast regions with inferior education and chaotic legal institutions, so that the future globalized world would be more unequal than the United States or the European Union today. If so, then the source of that inequality would be poor government and nondemocracy in those lagging countries, not globalization.

\section{References}

Abel, Wilhelm. 1973. Crises agraires en Europe, XIIIe-Xxe siècle. A translation of the 1966 edition of Agrarkrisen und Agrarkonjunktur. Paris: Flammarion.

Abowd, John M., and Michael L. Bognanno. 1995. International differences in executive and managerial compensation. In Differences and changes in wage structures, ed. Richard B. Freeman and Lawrence F. Katz, 25-66. Chicago: University of Chicago Press.

Aitken, Brian, Ann Harrison, and Robert E. Lipsey. 1996. Wages and foreign ownership: A comparative study of Mexico, Venezuela, and the United States. Journal of International Economics 40 (May): 345-71.

Allen, Robert C. 2000. Real wages in Europe and India 1595. Paper presented at the Conference on Asian and European Pre-Industrial Living Standards, 1-5 August, Arild, Sweden.

Allen, Robert C. 2001. The great divergence: Wages and prices from the Middle Ages to the First World War. Explorations in Economic History. 38 (October): 411-47.

39. And thus one that would satisfy any plausible size condition necessary to achieve scale economies.

40. Bourguignon and Morrisson (2002, tables 1 and 3). Milanovic (1999) gives a similar estimate for 1993 with an alternative set of household survey data. 
Atinc, Tamar Manuelyan. 1997. Sharing rising incomes: Disparities in China. Washington: World Bank.

Bairoch, Paul. 1972. Free trade and European economic development in the nineteenth century. European Economic Review 3 (November): 211-45.

1989. European trade policy, 1815-1914. In The Cambridge economic history of Europe. Vol. 8, ed. P. Mathias and S. Pollard, 1-190. Cambridge: Cambridge University Press.

Balassa, Bela. 1971. The structure of protection in developing countries. Baltimore: Johns Hopkins University Press.

Baldwin, Richard, and Philippe Martin. 1999. Two waves of globalization: Superficial similarities, fundamental differences. NBER Working Paper no. 6904. Cambridge, Mass.: National Bureau of Economic Research, January.

Barro, Robert J., and Xavier Sala-i-Martin. 1995. Economic growth. New York: McGraw Hill.

Basu, Kaushik. 1999. Child labor: Cause, consequence, and cure, with remarks on international labor standards. Journal of Economic Literature 37 (September): 1083-119.

Berman, Eli, John Bound, and Zvi Griliches. 1994. Changes in the demand for skilled labor within U.S. manufacturing: Evidence from the Annual Survey of Manufactures. Quarterly Journal of Economics 109 (May): 367-98.

Bernstein, Aaron, Michael Shari, and Elisabeth Malkin. 2000. A world of sweatshops. Business Week, 6 November, pp. 84-86.

Berry, Albert, François Bourguignon, and Christian Morrisson. 1983. Changes in the world distribution of income between 1950 and 1977. Economic Journal 93 (June): 331-50.

1991. Global economic inequality and its trends since 1950. In Economic inequality and poverty: International perspectives, ed. Lars Osberg, 60-91. Armonk, N.Y.: Sharpe.

Bhagwati, Jagdish, and Anne O. Krueger, eds. 1973-1976. Foreign trade regimes and economic development. Multiple vols. New York: Columbia University Press.

Boltho, Andrea, and Gianni Toniolo. 1999. The assessment: The twentieth century-achievements, failures, lessons. Oxford Review of Economic Policy 15 (4): $1-17$.

Bordo, Michael, Barry Eichengreen, and Douglas A. Irwin. 1999. Is globalization today really different than globalization a hundred years ago? NBER Working Paper no. 7195. Cambridge, Mass.: National Bureau of Economic Research, June.

Boskin, Michael, Ellen R. Dulberger, Robert J. Gorden, Zvi Griliches, and Dale W. Jorgenson. 1998. Consumer prices, the consumer price index, and the cost of living. Journal of Economic Perspectives 12 (Winter): 3-26.

Bourguignon, François, and Christian Morrisson. 1990. Income distribution, development, and foreign trade. European Economic Review 34 (September): 111332 .

2002. The size distribution of income among world citizens: 1820-1990. American Economic Review 92 (September): 727-44.

Braudel, Fernand P., and Frank C. Spooner. 1966. Prices in Europe from 1450 to 1750. In Cambridge economic history of Europe. Vol. 4: Sixteenth and seventeenth centuries, ed. Edwin E. Rich and Charles H. Wilson, 374-486. Cambridge: Cambridge University Press.

Brown, Drusilla K. 2001. Labor standards: Where do they belong on the international trade agenda? Journal of Economic Perspectives 15 (3): 89-112.

Burniaux, Jean-Marc, Thai-Thanh Dang, Douglas Fore, Michael Forster, Marco Mira d'Ercole, and Howard Oxley. 1998. Income distribution and poverty in se- 
lected OECD countries. OECD Economics Department Working Paper no. 189. Paris: Organization for Economic Cooperation and Development, March.

Chowdhury, Khorshed, Charles Harvie, and Amnon Levy. 2000. Regional income inequality in China. In Contemporary developments and issues in China's economic transition, ed. Charles Harvie, 238-61. New York: St. Martin's.

Clemens, Michael, and Jeffrey G. Williamson. 2000. Where did British foreign capital go? Fundamentals, failures, and the Lucas paradox 1870-1913. NBER Working Paper no. 8028. Cambridge, Mass.: National Bureau of Economic Research, December.

2001. A tariff-growth paradox? Protection's impact the world around 18751997. NBER Working Paper no. 8459. Cambridge, Mass.: National Bureau of Economic Research, September.

Cline, William R. 1997. Trade and income distribution. Washington, D.C.: Institute for International Economics.

Crystal, Graef. 1993. In search of excess: The overcompensation of the American executive. 2nd ed. New York: Norton.

Diakosavvas, Dimitris, and Pasquale L. Scandizzo. 1991. Trends in the terms of trade of primary commodities, 1900-1982: The controversy and its origin. Economic Development and Cultural Change 39 (January): 231-64.

Diaz-Alejandro, Carlos. 1970. Essays on the economic history of the Argentine Republic. New Haven, Conn.: Yale University Press.

Dollar, David. 1992. Outward-oriented developing economies really do grow more rapidly: Evidence from 95 LDCs, 1976-1985. Economic Development and Cultural Change 40 (April): 523-44.

Dollar, David, and Aart Kraay. 2000a. Growth is good for the poor. World Bank. Manuscript, March.

2000b. Trade, growth, and poverty. World Bank. Manuscript, October.

Edwards, Sebastian. 1992. Trade orientation, distortions, and growth in developing countries. Journal of Development Economics 39 (July): 31-57.

1993. Openness, trade liberalization, and growth in developing countries. Journal of Economic Literature 31 (September): 1358-94.

Eltis, David, and Stanley L. Engerman. 2000. The importance of slavery and the slave trade to industrializing Britain. Journal of Economic History 60 (March): 123-44.

Feenstra, Robert C., ed. 2000. The impact of international trade on wages. Chicago: University of Chicago Press.

Feenstra, Robert C., and Gordon H. Hanson. 1997. Foreign direct investment and relative wages: Evidence from Mexico's maquiladoras. Journal of International Economics 48 (2): 301-20.

1999. The impact of outsourcing and high-technology capital on wages: Estimates for the United States, 1979-1990. Quarterly Journal of Economics 114 (August): 907-40.

Firebaugh, G. 1999. Empirics of world income inequality. American Journal of Sociology 104 (6): 1597-630.

Flemming, John S., and John Micklewright. 2000. Income distribution, economic systems, and transition. In Handbook of income distribution. Vol. 1, ed. Anthony Atkinson and François Bourguignon, 843-917. Amsterdam: Elsevier Science.

Freeman, Richard B., and Lawrence F. Katz, eds. 1995. Differences and changes in wage structures. Chicago: University of Chicago Press.

Goldin, Claudia. 1994. The political economy of immigration restriction in the United States, 1890 to 1921. In The regulated economy: A historical approach to political economy, ed. Claudia Goldin and Gary D. Libecap, 223-57. Chicago: University of Chicago Press. 
Goldin, Claudia, and Lawrence F. Katz. 1999. The returns to skill in the United States across the twentieth century. NBER Working Paper no. 7126. Cambridge, Mass.: National Bureau of Economic Research, May. 2001. Decreasing (and then increasing) inequality in America: A tale of two half centuries. In The causes and consequences of increasing inequality, ed. Finis Welch, 37-82. Chicago: University of Chicago Press.

Greider, William. 1997. One world, ready or not: The manic logic of global capitalism. New York: Simon and Schuster.

Griffin, Keith, and Renwei Zhao, eds. 1993. The distribution of income in China. New York: St. Martin's.

Hadass, Yael, and Jeffrey G. Williamson. 2001. Terms of trade shocks and economic performance 1870-1940: Prebisch and Singer revisited. NBER Working Paper no. 8188. Cambridge, Mass.: National Bureau of Economic Research, March.

Hanson, Gordon, and Ann Harrison. 1999. Trade liberalization and wage inequality in Mexico. Industrial and Labor Relations Review 52 (January): 271-88.

Harrigan, James. 2000. International trade and American wages in general equilibrium, 1967-1995. In The impact of international trade on wages, ed. Robert C. Feenstra, 171-95. Chicago: University of Chicago Press.

Hatton, Timothy J., and Jeffrey G. Williamson. 1998. The age of mass migration. Oxford: Oxford University Press.

Hoffman, Philip T., David Jacks, Patricia A. Levin, and Peter H. Lindert. 2002. Real inequality in Western Europe since 1500. Journal of Economic History 62 (June): $322-55$.

Huber, J. Richard 1971. Effects on prices of Japan's entry into world commerce after 1858. Journal of Political Economy 79 (May-June): 614-28.

Irwin, Douglas A. 1988. Welfare effects of British free trade: Debate and evidence from the 1840s. Journal of Political Economy 96 (December): 1142-64.

- 1991. Was Britain immiserized during the Industrial Revolution? Explorations in Economic History 28 (January): 121-24.

Jacks, David. 2000. Market integration in the North and Baltic seas, 1500-1800. Working Papers in Economic History no. 55/00. London School of Economics, April.

Krueger, Anne O. 1983. The effects of trade strategies on growth. Finance and Development 20 (June): 6-8.

. 1984. Trade policies in developing countries. In Handbook of international economics. Vol. 1, ed. Ronald Jones and Peter Kenan, 519-69. Amsterdam: NorthHolland.

Lawrence, Robert Z. 2000. Does a kick in the pants get you going, or does it just hurt? The impact of international competition on technological change in U.S. manufacturing. In The impact of international trade on wages, ed. Robert C. Feenstra, 197-225. Chicago: University of Chicago Press.

Lawrence, Robert Z., and Matthew J. Slaughter. 1993. International trade and American wages in the 1980s: Giant sucking sound or small hiccup? Brookings Papers in Economic Analysis, Microeconomics, 2:161-226.

Lindert, Peter H. 2000. Three centuries of inequality in Britain and America. In Handbook of income distribution. Vol. 1, ed. Anthony B. Atkinson and François Bourguignon, 167-216. Amsterdam: Elsevier Science.

- 2001. Democracy, decentralization, and mass schooling before 1914. Agricultural History Center Working Paper no. 104. University of California-Davis, February.

Lindert, Peter H., and Jeffrey G. Williamson. 1985. Growth, equality, and history. Explorations in Economic History 22 (October): 341-77. 
Lucas, Robert. 1990. Why doesn't capital flow from rich to poor countries? American Economic Review 80 (May): 92-96.

Maddison, Angus. 1995. Monitoring the world economy, 1820-1992. Paris: Organization for Economic Cooperation and Development.

Melchior, Arne, Kjetil Telle, and Henrik Wiig. 2000. Globalization and inequality: World income distribution and living standards, 1960-1998. Studies on Foreign Policy Issues, Report 6B. Oslo: Royal Norwegian Ministry of Foreign Affairs, October.

Milanovic, Branko. 1999. True world income distribution, 1988 and 1993: First calculation based on household surveys alone. World Bank. Manuscript, October.

Nardinelli, Clark. 1990. Child labor and the Industrial Revolution. Bloomington: Indiana University Press.

Neal, Larry, and Paul Uselding. 1972. Immigration: A neglected source of American economic growth: 1790-1912. Oxford Economic Papers 24 (March): 68-88.

Obstfeld, Maurice, and Alan M. Taylor. 1998. The Great Depression as a watershed: International capital mobility over the long run. In The defining moment: The Great Depression and the American economy in the twentieth century, ed. Michael D. Bordo, Claudia Goldin, and Eugene N. White, 353-402. Chicago: University of Chicago Press.

O'Rourke, Kevin H. 1997. The European grain invasion, 1870-1913. Journal of Economic History 57 (December): 775-801.

. 2000. Tariffs and growth in the late nineteenth century. Economic Journal 110 (April): 456-83.

O’Rourke, Kevin H., Alan M. Taylor, and Jeffrey G. Williamson. 1996. Factor price convergence in the late nineteenth century. International Economic Review 37 (August): 499-530.

O’Rourke, Kevin H., and Jeffrey G. Williamson. 1999. Globalization and history. Cambridge: MIT Press.

. 2000. When did globalization begin? NBER Working Paper no. 7632. Cambridge, Mass.: National Bureau of Economic Research, April.

. 2002. After Columbus: Explaining Europe's overseas trade boom, 15001800. Journal of Economic History 62 (June): 417-56.

Pamuk, Sevket. 2000. Five hundred years of prices and wages in Istanbul and other cities. Ankara, Republic of Turkey: State Institute of Statistics.

Papageorgiou, Demetris, Michael Michaely, and Armeane M. Choksi, eds. 1991. Liberalizing foreign trade. Oxford, U.K.: Basil Blackwell.

Pavcnik, Nina. 2000. What explains skill upgrading in less developed countries? NBER Working Paper no. 7846. Cambridge, Mass.: National Bureau of Economic Research, August.

Pomeranz, Kenneth. 2000. The great divergence: China, Europe, and the making of the modern world economy. Princeton: Princeton University Press.

Prados de la Escosura, Leandro. 2000. International comparisons of real product, 1820-1990: An alternative data set. Explorations in Economic History 37 (January): $1-41$.

Pritchett, Lant. 1997. Divergence, big time. Journal of Economic Perspectives 11 (Summer): 3-18.

Radetzki, M., and B. Jonsson. 2000. The twentieth century-The century of increasing income gaps. But how reliable are the numbers? Ekonomisk Debatt 1:4358.

Robbins, Donald J. 1997. Trade and wages in Colombia. Estudios de Economia 24 (June): 47-83.

Robbins, Donald J., and Tim H. Gindling. 1999. Trade liberalization and the rela- 
tive wages for more-skilled workers in Costa Rica. Review of Development Economics 3 (June): 140-54.

Rodrik, Dani. 1997. Has globalization gone too far? Washington, D.C.: Institute for International Economics.

Sachs, Jeffrey D., and Andrew Warner. 1995. Economic reform and the process of global integration. Brookings Papers on Economic Activity, Issue no. 1:1-118. Washington, D.C.: Brookings Institution.

Schultz, T. Paul 1998. Inequality in the distribution of personal income in the world: How is it changing and why? Journal of Population Economics 11:307-44.

Slaughter, Matthew. 2000. What are the results of product-price studies and what can we learn from their differences? In The impact of international trade on wages, ed. Robert C. Feenstra, 129-69. Chicago: University of Chicago Press.

Taylor, Alan M. 1999. International capital mobility in history: The savinginvestment relationship. NBER Working Paper no. 5743. Cambridge, Mass.: National Bureau of Economic Research, September.

Taylor, Alan M., and Jeffrey G. Williamson. 1997. Convergence in the age of mass migration. European Review of Economic History 1 (April): 27-63.

Timmer, Ashley, and Jeffrey G. Williamson. 1998. Immigration policy prior to the 1930s: Labor markets, policy interactions, and globalization backlash. Population and Development Review 24 (December): 739-71.

Tuttle, Carolyn. 1999. Hard at work in factories and mines: The economics of child labor during the British Industrial Revolution. Boulder, Col.: Westview Press.

United Nations Conference on Trade and Development. 1988. Handbook of international trade and development statistics 1987. New York: United Nations.

-1997. Handbook of international trade and development statistics 1995. New York: United Nations.

U.S. Department of Commerce. 1975. Historical statistics of the United States. Part 1. Washington, D.C.: U.S. Bureau of the Census.

U.S. Department of Labor, Bureau of International Affairs. 1995-2000. By the sweat and toil of children. Six vols. Available at [http://dol/ilab/media/reports/iclp/ sweat/], October 2000.

van Zanden, Jan Luiten. 1995. Tracing the beginning of the Kuznets curve: Western Europe during the early modern period. Economic History Review 48 (November): 643-64.

. 1999. Wages and the standard of living in Europe, 1500-1800. European Review of Economic History 3 (August): 175-98.

Ward, Marianne H. 2000. Re-estimating growth and convergence for developed economies: 1870-1990. Ph.D. diss. University of Miami-Coral Gables.

Williamson, Jeffrey G. 1990. The impact of the Corn Laws just prior to repeal. Explorations in Economic History 27 (April): 123-56.

. 1995. The evolution of global labor markets since 1830: Background evidence and hypotheses. Explorations in Economic History 32 (April): 141-96.

1996. Globalization, convergence, and history. Journal of Economic History 56 (June): 277-306.

1997. Globalization and inequality: Past and present. World Bank Research Observer 12 (August): 117-35.

2002. Land, labor, and globalization in the third world, 1870-1940. Journal of Economic History 62 (March): 55-85.

Williamson, Jeffrey G., and Peter H. Lindert. 1980. American inequality: A macroeconomic history. New York: Academic Press.

Wolff, Edward N. 1991. Capital formation and productivity convergence over the long term. American Economic Review 81 (June): 565-79. 
Wood, Adrian. 1994. North-south trade, employment, and inequality. Oxford, U.K.: Clarendon Press.

1997. Openness and wage inequality in developing countries: The Latin American challenge to East Asian conventional wisdom. World Bank Economic Review 11 (January): 33-57.

1998. Globalisation and the rise in labour market inequalities. Economic Journal 108 (September): 1463-82.

World Bank. 1983-2001. World development report. Washington: Oxford University Press.

Wright, Gavin. 1990. The origins of American industrial success, 1879-1940. American Economic Review 80 (September): 651-68.

Yasuba, Yasukichi. 1996. Did Japan ever suffer from a shortage of natural resources before World War II? Journal of Economic History 56 (September): 543-60.

\section{Comment Lant Pritchett}

I would be a fool to attempt to summarize what is a masterful review and summary of the literature on the relationship between globalization and inequality, both within and across countries. So, I will limit myself to five comments that both place the existing paper in context and poke around some of the puzzles that current events and attitudes raise.

First, I think too much too soon is being made of the relationship between trade liberalization and inequality. Some have suggested that the rise in inequality (and increase in skill differentials in labor markets) in some countries undergoing trade liberalization both contradicts the standard model and, more fundamentally, challenges the desirability of liberalization.

Suppose the wage profile of educational attainment (which is the usual proxy for "skill differentials") represents two effects. One is that educated people have more skills. The other is that educated people are more likely to adapt quickly and are more likely to be Schumpeterian entrepreneurs who reallocate factors across uses in the face of disequilibrium.

Suppose there is a liberalization between a human-capital-rich and a human-capital-poor country that represents a substantial shift for the humancapital-poor country. Then there will be two effects on inequality. In both countries the returns to entrepreneurship will rise, which, if this is positively associated with education, will steepen the wage-education attainment profile. This disequilibrium effect should emerge and then gradually go away as the economy settles down to its new steady state. According to the standard, simple theory the factor abundance effect should work in different directions - raising skill premiums in the skill-rich country and lowering the skill premiums in the skill-poor country. 
In the skill-rich country these effects are in the same direction so there is an unambiguous increase in inequality. In the skill-poor country these effects work in opposite directions so that, depending on their relative magnitudes, inequality could rise, stay the same, or fall in the short to medium run. Until we have sufficiently ruled out these "adjustment to disequilibria" effects on relative wages I would hesitate to say not only that factor abundance theories have been rejected by the data, but that the factor abundance stories have even been challenged by the data.

Second, the question of globalization and inequality across countries is often driven by the fact that some of the "nonglobalizers" had extraordinarily poor performance. This actually raises something of a puzzle as the "Harberger triangle" effects are typically too small by an order of magnitude to explain the 2 percentage point per annum growth deficit maintained over thirty or more years implied by the growth rates of the nonglobalizers.

I think the reconciliation will come in the structure of the instruments that the General Agreement on Tariffs and Trade (GATT) allowed developing countries to use. I have examined in detail five different developing countries' trade restrictions, and in four of those countries the restrictions were based on a system of three categories of licenses for imports plus a system for licensing foreign exchange (that would come and go). Imports were classified into three groups: (a) freely importable, (b) banned, or (c) imported with a license. This requirement of licensing acted as neither a tariff nor a quota. That is, unlike some types of import rationing in the United States, this type of licensing scheme did not specify a given quantity of men's cotton pants or tons of sugar. Rather, they were discretionary licenses based on a criterion that granted substantial discretion (e.g., whether they were "in the national economic interest").

This meant that the licenses could be made specific not only to the import type but also to the use to which the import was to be put and even to the particular importer (so that public-sector firms could be preferred over private-sector ones, established firms over start-ups-which could not demonstrate "need" - or bribe payers over non-bribe payers). This aspect of the discretionary specificity meant that the usual market clearing conditions for estimating production or welfare losses from restricting imports did not apply. That is, in order to estimate a Harberger triangle from reducing import quantities by 10 percent one needs to assume that the lowest valued users (in the consumer surplus sense) were those rationed out. However with discretionary and specific import licenses this need not be the case as high-value private users could be rationed out in favor of low-value, publicsector firms. Without either perfect bribery or perfect resale market (which did not exist in the cases I studied), the Harberger triangle was replaced by a series of rectangles and the "second order-ness" of production losses from import restrictions could not be guaranteed.

What does this mean for the current paper? One cannot really compare 
the growth effects of being "protectionist" or a "nonglobalizer" across historical epochs because the instruments used and the intensity with which they were used vary so widely. In the pre-WWII era there were primarily tariff-based restrictions (and most "developing" countries were colonies). In the post-WWII system, developing countries entered the GATT in such a way that more or less exempted them wholesale from any discipline on the instruments used to provide import protection (or the intensity of the use of these instruments). So, while the developed countries moved toward exclusive use of tariffs (except, of course, for obvious exceptions such as multifiber arrangements) the developing countries used primarily nontariff barriers. This use of nontariff barriers, explicitly allowed to cope with the balance of payments, combined with the system of "fixed" exchange rates with periodic revaluations to produce the worst of all worlds. Foreign exchange "shortages" from overvalued exchange rates were met with the use of discretionary import licenses specific to both use and importer-and these have the potential to do almost unlimited economic damage. So I would argue that being a "protectionist" country in the 1970s and 80s has almost no comparison to the "protectionism" of the 1920s and 30s.

Third, what is it about inequality that is so worrisome? Is it inequality across countries? Is it inequality within one('s own) country? Is it increases in the volatility of individual incomes (even if cross-sectional inequality does not increase)? More specifically, if the Seattle-Quebec protester crowd were to read and understand this paper, would they stop their antiglobalization agitation? In part, that depends on what one thinks the protestors are agitated about. I approach this question with a pinch of Bob Dylan's "Senators, Congressmen throughout the land, don't criticize what you can't understand," as I do not really understand what it is that gets the protestors in the streets.

Here are four conjectures, however, each of which might lead to different reactions:

1. U.S. labor unions: concerns about declining real wages in the United States, both directly through changes in factor abundance and indirectly via capital mobility effects that have reallocated economic power (and sharing of rents) between labor and capital.

2. Nongovernmental organizations (NGOs): concerns about inequality across nations, particularly the performance of the poorest.

3. Fear of falling: concerns about the increase in volatility caused by increasing linkages so that white-collar middle managers can lose their jobs because of financial crises in Russia.

4. Hiding costs: concerns that globalization makes it harder to maintain high levels of social transfers as the costs of measures to transfer resources from consumer to certain groups of producers (e.g., farmers in Europe) is made politically more transparent by freer trade. 
I think this paper should reassure the NGO crowd. I do not think there is anything in the evidence to suggest that globalization per se or participation in globalization has been bad for raising levels of income in the poorest countries.

However, after devoting all of my professional life to the problems of poor countries, I am not convinced that concern about poorer countries is large enough to generate any political pressure. I personally suspect that the other three motivations are behind the Seattle antiglobalization movement.

Fourth, there are three puzzles and one possible, partial solution, with respect to reconciling the literature on globalization with individual country experience. That is, if we imagine that globalization is the process of leading to deeper integration of financial, goods, and labor markets, then variation in the size of countries should provide some indications about the likely direction and magnitudes of globalization impacts. First, it is not the case that larger countries (whether with respect to population or land size), which have larger markets with or without globalization, have on average substantially higher levels of income. The countries in the world with more than 100 million people are (in order of population size) China, India, the United States, Indonesia, Brazil, the Russian Federation, Pakistan, Bangladesh, Japan, and Nigeria. This is obviously not compelling, as size of market depends on outward orientation as well as on intrinsic size, but large-scale effects in the level of income do not leap off the page. Second, in terms of inequality it is also not clear there is any relationship between inequality and country size, although here the question for globalization is whether regions that are not integrated as a single country would have lower inequality if they were. Finally, one fact that I am very puzzled by is the very weak forces for convergence even within regions of many developing countries. Even with urban-rural and cross-regional migration, inequality in per capita incomes has not decreased in Brazil, India, or China. It seems within countries there should be rapid and absolute convergence.

The one possible resolution of the size puzzle is that what matters for the gains from scale is the size of the market over which one can reliably contract - as that determines investments in the concentration of production and in specialization of assets. If, however, the legal and political systems contain substantial uncertainty about the appropriability of future profit streams, then the true size of the market over which a producer can reliably contract could be orders of magnitude different - even for the same size market because all future flows are so highly discounted.

Fifth, a final issue in globalization and inequality is that counteracting the globalizing forces is a huge increase in the numbers of nation-states. That is, the post-WWII period has seen an increase from maybe 50 completely independent, internationally sovereign states to more than 200. I am currently working with Ricardo Hausmann on a project in which we estimate the growth and income effects of this increasing division of the eco- 
nomic space into units that have their own trade policies (not matter how outwardly oriented), their own currency, their own contract enforcement, and their own restrictions on labor mobility.

All in all, this is a wonderful paper as it both informs with new facts and provokes with new thoughts. 
